\title{
RETHINKING ISLAMIC THEOLOGY Mengagas Teologi Sosial dalam Konteks Pluralisme dan Multikulturalisme (Perspektif Pemikiran Teologi Fethullah Gulen)
}

\author{
Muhammad Said \\ Peneliti Pusat Studi Islam Asia Tenggara \\ Saidfil2@gmail.com
}

\begin{abstract}
This article elaborate about the neccesity of renewal Islamic theology in the context of pluralism and multiculturalism. One of contemporary Muslim schoolars, Fethullah Gulen, could be considered among the most influential Muslim theologians of our time. His work focus on redefining the nature of Islamic discourse in the contemporary world by doing interreligious and intercultural dialogue. Today, we need to shift our paradigm from classical kalam which dogmatic, abstract, and exclusive to more practical theology based on life and contemporary needs, which is called "social theology". Gulen's theological discourse distinguished for his support of democracy, humanisme, openness to globalization, progressiveness in integrating tradition with modernity, and to make sense of pluralistic-piety.
\end{abstract}

Keyword: Kalam, Social-Theology, Pluralitic-Piety, Multiculturalisme

\begin{abstract}
Abstrak. Artikel ini menguraikan tentang necseity pembaharuan teologi Islam dalam konteks pluralisme dan multikulturalisme. Salah satu murid sekolah Muslim kontemporer, Fethullah Gulen, dapat dianggap sebagai salah satu teolog Muslim paling berpengaruh di zaman kita. Karyanya fokus pada mendefinisikan kembali sifat wacana Islam di dunia kontemporer dengan melakukan dialog antaragama dan antarbudaya. Saat ini, kita perlu menggeser paradigma kita dari kalam klasik yang dogmatis, abstrak, dan eksklusif ke teologi yang lebih praktis berdasarkan pada kehidupan dan kebutuhan kontemporer, yang disebut "teologi sosial". Wacana teologis Gulen dibedakan atas dukungannya terhadap demokrasi, humanisme, keterbukaan terhadap globalisasi, progresifitas dalam mengintegrasikan tradisi dengan modernitas, dan untuk memaknai kesalehan pluralistik.
\end{abstract}

Kata kunci: Kalam, Teologi Sosial, Pluralitic-Piety, Multikulturalisme

\section{Pendahuluan}

Globalisasi sebagai zaman yang tidak bisa dihindari ${ }^{1}$, telah banyak merubah

${ }^{1}$ Globalisasi di bidang pengetahuan, kekuasaan dan teknologi senantiasa diiringi oleh peluang munculnya konflik antar budaya dan peradaban. globalisasi mengacu pada perkembangan pesat dalam bidang teknologi komunikasi, informasi dan transportasi, yang telah menciptakan bagianbagian terpencil dunia dan peristiwa-peristiwa berskala lokal mudah diakses oleh segenap warga dunia. Maka dengan keterbukaan tersebut sangat memungkinkan terciptanya benturan antar budaya dan peradaban. Giddens menjelaskan, bahwa globalisasi sangat dekat hubunganya dengan risiko, dan globalisasi merupakan dunia yang tak terkendali. meskipun demikian, Giddens tidak 
struktur dan sistem sosial di tengah masyarakat. Pluralitas dan multikulturalitas menjadi semakin kontras dalam berbagai aspek kehidupan. Kondisi ini jika tidak dikelola dengan baik, akan sangat rentan memunculkan konflik, dan sekaligus merupakan ancaman bagi integrasi sosial sebuah bangsa. Struktur masyarakat yang hiper-plural dewasa ini, seakan-akan semakin menguatkan ramalan Samuel huntington, tentang kemungkinan terjadinya "clash of civilization."

Secara umum, ada tiga bentuk keragaman dalam masyarakat modern. Pertama, keragaman subkultur; kearagaman ini ditandai dengan munculnya subkultur-subkultur baru diluar kultur dominan. Kedua, keragaman persfektif; keragaman ini muncul dari anggota masyarakat yang kritis terhadap nilai-nilai dominan (Grand narasi) yang dianggap tidak ideal dan harus dievaluasi untuk memperbaiki keadaan, hal ini misalnya muncul gerakan feminist dalam dunia Islam, sebagai kritik terhadap nila-nilai normatif yang patriarkal. Ketiga, keragaman komunal; keragaman ini muncul bila terdapat anggota-anggota masyarakat yang hidup secara berkelompok, terorganisir dengan baik, memiliki sistem dan norma hidup yang berbeda dari masyarakat pada umumnya. Misalnya munculnya gerakangerakan keagamaan baru. ${ }^{2}$

pesimis terhadap kondisi dunia yang tak terkendali, ia masih menaruh harapan pada demokrasi untuk menjembatani berbagai persoalan yang muncul di tengah arus globalisasi dan multukulturalitas, lihat Athony Giddens, The consequences of modernity (Cambridge : Polity Press, 1990) hlm. 64, lihat George Ritzer terj. Saut pasaribu dkk, Teori Sosiologi ; Dari Sosilogi klasik Sampai Perkembangan Terakhir Posmodern ( Yogyakarta, Pustaka pelajar,2012) hlm. 979

2Bikku Parekh dalam Lucia Ratih Kusuma Dewi“ kembalinya Subyek : sosiologi memaknai kembali multkulturalisme" jurnall sosiologi masyarakat. hlm.74
Dalam konteks Indonesia, problem paling akut dalam soal pluralisme dan multikulturalisme adalah konflik intra dan antar ummat beragama. Hal ini tanpa bermaksud meminggirkan problemproblem lain, seperti konflik antar etnis, kekerasan gender dan marginalisasi atas kelompok yang memiliki "orientasi seksual berbeda"- LGBTQ- di ruang Publik. Menurut catatan nasional kompas, Identitas keberagaman di Indonesia terus diuji dengan beragam tindakan diskriminasi. Selama 14 tahun pasca-reformasi, setidaknya ada 2.398 kasus kekerasan dan diskriminasi yang terjadi di Indonesia. Yayasan Denny JA mencatat, dari jumlah itu kekerasan yang palin banyak adalah yang disebakan oleh latabelakang agama atau paham kegamaan, yakni dengan angka sebanyak 65 persen. Sisanya, secara berturut-turut adalah kekerasan etnis (20 persen), kekerasan jender (15 persen), dan kekerasan orientasi seksual (5 persen). ${ }^{3}$

Berdasarkan catatan di atas, jelas bahwa rating tertinggi sebagai penyebab munculnya kekerasan adalah agama. Tentu hal ini sangat ironis, agama yang sejatinya mengajarkan cinta dan kasih, menjanjikan kedamaian dan keselamatan, justru menjadi ancaman dan malapetaka bagi manusia. untuk memahami kenapa hal itu bisa terjadi, sepertinya menarik mengutip pendapat Charles Kimball, menurutnya, ada lima hal yang membuat agama menjadi korup dan busuk; Pertama, truth claim; sikap ini muncul dari pemahaman rigid atas kitab suci dan boleh jadi kitab suci disalahgunakan ademi hasrat kuasa dan kepentingan. akibatnya pemeluk agama bersikap antipati terhadap eksitensi pemeluk agama lain. Kedua, "fanatik buta" kepada pemimpin agama. ketiga,

${ }^{3}$ http://nasional.kompas.com/read/2012/1 2/23/15154962/Lima.Kasus.Diskriminasi.Terburuk. Pascareformasi. Diakses 26-06-2015. 
romantisme pemeluk agama atas zaman ideal masa lampau, kemudian memaksakan kehendak untuk merealisasikanya kembali di masa sekarang. Keempat, Pelembagaan agama dan penciptaan kuasa, seperti telah terjadi dalam gereja katolik, bahwa gereja adalah pemegang kunci "pintu keselamatan". Kelima, ketika genderang perang suci (red-jihad) mulai ditabuhkan. ${ }^{4}$

Hal-hal yang dipaparkan dia atas oleh Kimball memiliki relasi atau berkaitkelindan dengan persoalan konsep dan pemahaman teologi. Dalam dunia Islam, teologi identik dengan ilmu kalam. Ilmu kalam adalah ilmu yang membahas dasardasar Akidah (beliefe) terutama termaterma ketuhanan dan ekskatologis. Teologi sebagai The intellectual expression of religion bersifat dogmatis dan abstrak. selain itu, konsep teologi Islam klasik bersifat sektarian dan cenderung bersifat eksklusif. Hal itu dapat dilihat pada fase awal sejarah kemunculanya, dilatarbelakangi oleh konflik politik kemudian menjadi perdebatan wacana teologis yang sangat agresif, bahkan hingga memunculkan korban jiwa. Beberapa tragedi dalam narasi sejarah Islam, menceritakan bahwa pemahaman teologi seringkali diselingkuhkan dengan kekuasaan, kemudian melahirkan "anak haram" dalam wujud "tirani" atas kelompok lain, sesama Islam, pun atas kelompok nonMuslim.

Paper ini mengasumsikan bahwa krisis multikulturalisme, yang memunculkan konflik dan kekerasan disebabkan oleh multi-faktor; agama, politik, sosial, ekonomi, etnik dan budaya. Namun, penulis tidak hendak mengambil seluruh faktor tersebut untuk dibahas dalam paper ini. penulis hanya akan $\mathrm{m}$ embahas faktor

${ }^{4}$ Charles kimball, When Religion Become Evil terj. Nurhadi dan Izzudin Wasil (Bandung : Mizan, 2013) hlm. XIV-XXI agama (teologi-red) sebagai faktor dominan. Konflik yang berakar pada persoalan teologi-dalam hal ini teologi Islam- disebakan oleh pemahaman yang literalis-dogmatis, eksklusif-spekulatif, dan agresif (radikal). tidak bisa dinafikan bahwa corak kalam klasik memang masih mengisi nalar teologis sebagian ummat Islam dewasa ini. Hal itu bisa dilihat dari sikapsikap reaksioner dan radikal dari kalangan tertentu dalam merespon persoalan multikultural. dari itu, penulis dalam paper ini memfokuskan pada pemikiran kosmopolit Fethullah Gulen, seperti dialog antar agama, dan antar peradaban. Selain itu, ia juga melakukan upaya revitalisasi nilai-nilai etik religius universal ke dalam konteks kehidupan modern-multikultural, sehingga Islam dan nilai-nilai modernitas menjadi kompatibel. Pemikiran-pemikiran Fethullah Gulen itu kemudian penulis sebut sebagai "teologi sosial", dalam pengertian bahwa pemikiran-pemikiranya merupakan pandangan dunianya yang terkonstruk dari pemahamanya tentang agama (teologis) dan dialektika kehidupan sosial. Paper ini akan akan membahas rethinking kalam dengan melacak kembali genealoginya, kritik atas paradigma kalam klasik, menjelakan urgenya paradigma teologi sosial sebagi pardigm shift dalam berteologi dan membahas diskursus pemikiran teologi Fethullah Gulen yang meliputi; Tauhid berdasarkan cinta dan humanisme, Nabi Muhammad: Inspirator sense of multiculturalism, Hizmet : aktivisme sosial untuk kemanusiaan.

\section{A. Sekilas tentang Fethullah Gulen}

Fethullah Gulen adalah seorang tokoh Muslim kontemporer. lahir di Erzurum pada tahun 1941 di daerah bagian timur Turkey. ${ }^{5}$

${ }^{5}$ Fethullah Gulen,Toward Global Civilization of Love and Tolerance "( New jersey :The Light, 2004). hlm. xi 
ia seorang pemikir, penulis prolifik dan juga seorang sastrawan. Gulen tumbuh dalam keluarga yang religius. Ayahnya Ramiz Afandi dikenal sebagai Ulama yang santun. Ibunya Rafi'ah Hanim dikenal sebagai wanita sholehah. Pada masa anak-anak, ia belajar ilmu agama di surau-surau. Diantara guru-gurunya Usman Bektasy seorang Faqih terkenal pada masa itu. Selain belajar ilmu agama Gulen juga belajar ilmu sosial, ilmu Alam dan Filsafat. Perjalanan pemikiran banyak dipengaruhi oleh beberapa "sufi master". Diantara para Sufi yang mempengaruhi pemikiranya adalah Ibnu Araby, Jalaluddin Rumi dan Said Nursi. Nama terakhir adalah sosok yang paling berpengaruh bagi Gulen lewat karyanya Risale al-Nur.

Pada tahun 1958, ia mendapatkan nilai Ujian execellent, dalam seleksi muballigh. Ia bahkan mendapat penghargaan " a state preacher's license". kemudian a ditugaskan di Izmir, sebuah daerah terbesar ketiga di daratan turki. Dari sini, Gulen memulai mengembangkan dan menyebarkan ideidenya pada khlayak. Dalam berbagai kesempatan, ceramah-ceramahnya selalu diunukan kepada para generasi muda agar peka terhadap permasalahan-permasalahan sosial. ia juga memberikan pencerahan pada generasi muda akan pentingya mensinergikan antara kecerdasan intelektual, kearifan spiritualitas dan aksi nyata untuk kemanusiaan. ${ }^{6}$

Sebagai penceramah, Gulen menyampaikan ide-idenya tidak hanya di ruang masjid saja, namun ia juga aktif berbicara dalam seminar-seminar, pelatihan-pelatihan, bahkan berdiskusi di warung kopi sekalipun. semua itu dilakukan untuk menyebarkan ide-ide perdamain dan menciptakan kehidupan dunia yang harmonis.

${ }^{6}$ Fethullah Gulen, Toward Global..., hlm xi
Kesarjanaan Gulen adalah di bidang pemikiran Islam, terutama tasawuf dan dialog interreligious and Cultural. diantara karya Gulen yang telah diterjemahkan ke dalam bahasa inggris adalah ; Prophet Muhammad; aspect of his life, Questions and Answer about faith, pearls of wisdom, porphet Muhammad as Comander, the esential of islamic faith, toward the lost paradise, key conceptin practice of sufism dan banyak lagi yang sudah di terjemahkan ke dalam berbagai bahasa seperti, german, albania, jepang dan Indonesia.

Gulen merupakan aktifis Interfaith dialogue dan Intercultural dialogue. Ia menekakan pentingnya mengembangakan dialog lintas agama, suku, dan budaya. Pada tahun 1999 ia mempresentasikan papernya sebagai perwakilan agama-agama dunia di cafe town dengan judul " The Neccessity of Interfaith Dialogue"7. Dalam pidato tersebut, ia menegaskan bahwa dialog merupakan sebuah keharusan, bagi tokoh agama, tokoh politik dan para pengampu kebijakan.

Sebagai seorang publik figur, Gulen memiliki banyak pengikut. Ide-ide besar Gulen tentang spritualitas dan ajaran tentang "kepedulian terhadap sesama" (Hizmet), diejawantahkan oleh para pengikutnya ke dalam bentuk aktivisme sosial. para pengikut Gulen mengagas Gulen Movement; semacam gerakan civil society yang fokus pada program-program kemanusiaan. Salah satu agenda gerakan tersebut adalah upaya mensejahterakan masyarakat, baik di dalam maupun di luar Turki. Gerakan ini mendirikan sekolahsekolah dan institusi sosial lainya seperti rumah sakit, pusat kursus dan lain-lain. Pendanaan gerakan ini disupport oleh para pengusaha atau orang-orang kaya yang dermawan. Untuk lembaga pendidikan,

${ }^{7}$ Fethullah Gulen, Toward...,hlm xi 
guru-guru yang mengajar juga orang-orang yang memiliki semangat voluntarsime. Hingga saat ini, Sekolah-sekolah Gulen telah tersebar ke berbagai belahan dunia. Mulai dari Turki bagian Tenggara, Asia tengah, Asia Timur dan Tenggara, Eropa dan Amerika.

\section{B. Genealogi Kalam : Persfektif sosio- politik}

Ketika gerak laju zaman terus mengalir, tatanan dan struktur kehidupan dunia dalam berbagai aspek mengalami perubahan. di situlah kemudian konsepkonsep kalam klasik yang bersifat eksklusif dan abstract harus digeser menjadi teologi yang membumi dan memiliki kontribusi dalam kehidupan sosial-kontemporer. rethinking kalam dalam hal ini menjadi urgen. Dan hal itu harus dimulai dari pembacaan kembali sejarah Islam. Karna lewat sejarah, kita bisa melacak genealogi dan konteks perdebatan teologis pada fasefase awal. Langkah ini merupakan ikhtiar untuk melacak bagaimana "kalam" muncul dalam narasi sejarah, dengan mencermati konteks sosio-politik saat itu. Sejarah sebagai sebuah kronologi, merupakan rentetan kejadian yang terjadi dalam suatu fase tertentu yang tidak selalu objektif, karna acapkali dikonstruk oleh para penguasa.

Menurut Dawam Raharjo, sejarah adalah cabang ilmu sosial yang sangat dekat dengan politik, Persepsi ini terbentuk berdasarkan bahwa narasi-narasi sejarah yang ditemukan selalu berbicara tentang sejarah raja-raja (penguasa), sejarah timbul-tenggelamnya kerajaan, kejayaan dan keruntuhan suatu dinasti dan sejarah bangun dan runtuhnya rezim-rezim politik. ${ }^{8}$

8Dawam Rahardjo, Analisis Transformasi Masyarakat, dalam Kuntowijoyo "Paradigma Islam : Interpretasi untuk aksi" (Bandung : Mizan Pustaka, 2008) hlm.17
Demikian pula sejarah munculnya kalam, yang diawali oleh proses perseteruan politik. Sebagaimana pendapat Harun Nasution, bahwa latar belakang munculnya "ilmu kalam" dilatarbelakangi oleh perseteruan politik (khilafah), kemudian bergerser kepada isu-isu teologis. ${ }^{9}$

Berbeda dengan Harun Nasution, Abdullah Saeed berpendapat bahwa problem-problem teologis dikalangan ummat Islam sudah berlangsung sejak zaman Rasul. Suatu Hadis yang menceritakan bahwa ada sekolompok sahabat sedang berbincang-bincang tentang ketentuan (taqdir) Tuhan atas sebuah kejadian, kemudian, konon Nabi melarang mereka untuk terlalu banyak membahas soal tersebut. Bahkan nabi pun melarang para sahabat untuk berdebat tentang hakikat Tuhan. ${ }^{10}$ Pendapat yang dikemukan Abdulah Saeed memang benar, tetapi harus dicermati bahwa pertanyaan-pertanyaan sahabat seputar keesaan Tuhan, sifatsifatNya, hari kiamat dan lain-lain, hanya sebatas diskusi biasa yang tidak memunculkan perpecahan dan aliran-aliran kalam pada saat itu.

Ketika nabi wafat pada tahun $632 \mathrm{M}$, daerah kekuasaan Madinah padasaat itu meliputi serikat seluruh suku-suku yang ada di semenanjung Arab, termasuk Makkah. ${ }^{11}$ Maka Islam saat itu selain sebagai agama, juga menjadi sistem politik. ${ }^{12}$ Dengan demikian, secara otomatis, Nabi Mumamad menjadi rasul dan pemimpin negara. Oleh karena itu, wafatnya

${ }^{9}$ Harun Nasution, Teologi Islam: aliranaliran, sejarah, analisa dan perbandingan, (Jakarta : UI Press : 2012) hlm.3

10Abdullah Saeed, Islamic Thought: an Introduction, (New York : Rouledge, 2006) hlm. 61

11W.M. Watt, Muhammad Prophet and Statesman, (Oxford : University Press, 1961) hlm. 222

12Lihat, Shorter Encyclopedia of Islam, (Leiden: University press, EJ.Brill, 1962) hlm. 534 
Nabi, memunculkan perdebatan tentang siapakah yang pantas menggantikan beliau sebagai kepala negara (khalifah). Sejarah mencatat, bahwa Abu Bakar lah yang disetujui ummat Islam saat itu, kemudian diganti oleh Umar Ibn al-Khattab, kemudian Umar digantikan Usman Ibn affan.

Era kepemimpinan Abu Bakar dan Umar berjalan relatif aman dan sukses serta tidak banyak masalah. Ketika Usman Ibn Affan (w.656 M) naik menjadi Khalifah ketiga, pemerintahan diwarnai oleh manuver-manuver politik, yang menyebabkan munculnya perlawanan dari kalangan sahabat. Diantara kebijakanya yang kontroversial adalah memecat gubernur-gubernur yang telah diangkat pada era kepemimpinan Umar. ia kemudian mengganti pejabat-pejabat era Umar dengan orang-orang terdekatnya (lingkaran keluarga). Jika dilihat dari sudut pandang politik modern, tindakan ini bisa disebut sebagai tindak nepotisme. Salah satu gubernur yang dipecat saat itu adalah gubernur Mesir; Umar Ibn al-'As, diganti dengan Abdullah Ibn sa'd Ibnu Abi Sarh; ia adalah kalangan keluarga Usman. ${ }^{13}$ Keputusan ini kemudian menyebabkan instabilitas pemerintahan dan memuncukan pemberontakan-pemberontakan, yang berujung pada terbunuhnya sang khalifah.

Pasca wafatnya Usman, Ali menjadi kandidat terkuat sebagai Khalifah. Namun perjalanan Ali tidak mulus begitu saja, karena mendapat tantangan dari tokohtokoh lain yang ingin mejadi khalifah semisal Thalhah dan Zubair dari Makkah yang didukung oleh Siti 'Aisyah. Namun dua tokoh oposisi ini berhasil ditumpas oleh Ali dalam peperangan yang terjadi di Irak tahun 656 M. ${ }^{14}$ Dua tokoh itu terbunuh, sedangkan Aisyah dipulangkan ke Makkah. Gelombang anti Ali kemudian datang dari

${ }^{13}$ Harun Nasution, Teologi..., hlm. 6

${ }^{14}$ Harun Nasution, Teologi..., hlm. 6
Mu'awiyah (w.680 M); gubernur Damaskus. Ia tak mau mengakui Ali sebagi Khalifah. Ia menuntut Ali untuk mengusut tuntas skandal pembunuhan Usman. bahkan Mu'awiyah menuduh Ali terlibat dalam konspirasi pembunuhan tersebut. Karena pembunuh Usman ternyata Ibn Abi Bakr, ia adalah anak angkat Ali Ibn Abi Tholib. ${ }^{15}$ Sedangkan Ali tidak menindak tegas pelaku pembunuhan tersebut.

Pemberontakan Mu'awiyah terhadap Ali pada akhirnya memunculkan perang shiffin, tentara Ali berhasil mengalahkan pasukan Mu'awiyah. Dalam kondisi kalah, staf ahli Mu'awiyah; Amru Ibn al-As memainkan strategi diplomatik, dengan mengangkat al-Qur'an ke atas sebagai tanda ingin berdamai. Maka sebagian pendukung Ali medesak Ali supaya menerima tawaran tersebut demi mewujudkan perdamaian. Kemudian terjadilah kesepakatan untuk melakukan arbitrase. Masing-masing kelompok diwakili oleh seorang tokoh, Amru Ibn al-as dari pihak Mu'awiyah dan Abu Musa al-Asy'ari dari pihak Ali. ${ }^{16}$ Proses diplomasi antara dua kubu tersebut, melahirkan kesepakatan untuk menjatuhkan kedua pemimpin yang bertikai; Ali dan Mu'awiyah. Abu Musa alAsy'ari sebagai tokoh yang dituakan (senior), dipersilahkan terlebih dahulu memberikan pernyataan (statemen politik) untuk menjatuhkan kedua pimpinan yang sedang bertikai. ia pun menyampaikan hal tersebut di hadapan khalayak saat itu. Ketika Tiba giliran Amru Ibn al-Ash untuk menyampaikan statemen politiknya, tibatiba ia hanya menyetujui statemen Abu Musa dalam penjatuhan Ali, dan tidak setuju terhadap penjatuhan Mu'awiyah. ${ }^{17}$

\footnotetext{
15Ibnu Jarir, Tari $>$ kh al-Thabari ( kairo : Da>r al-ma'arif, 1963, jilid V) Hlm.7

${ }^{16}$ Abdullah Saeed, Islamic...,hlm.61

17Ibnu Jarir, Tarikh Al-thabari...,hlm.70-71
} 
Peristiwa tersebut tentunya sangat merugikan Ali. Mua'wiyah sebagai pihak oposisi seolah-olah naik tingkat menjadi khalifah, berdasarkan keputusan dalam arbitrase tersebut. Ali sebagai pihak yang dicurangi, tidak mau menerima keputusan itu, sehingga terjadi pertikaian yang panjang antar dua kelompok tersebut. Sebagian pendukung Ali yang sejak awal tidak sepakat dengan proses arbitrase tersebut, mulai menarik diri dan memusuhi Ali. Mereka beralasan bahwa tidak boleh menerima keputusan dari manusia. Karena yang berhak memutuskan hanyalah Allah. Kelompok ini kemudian disebut Khawarij. ${ }^{18}$ Khawarij menuduh semua orang yang terlibat dalam proses arbitrase tersebut menjadi kafir, karena telah menggunakan hukum selain hukum Allah. Sebagaimana yang dijelaskan dalam QS. Al-Maidah : $44 .^{19}$ Karena telah kafir, maka mereka wajib dibunuh. Namun diantara keempat tokoh itu, yang berhasil terbunuh adalah Ali. Sehingga kematian Ali semakin memuluskan jalan Mu'awiyah sebagai khalifah.

Perubahan konsep kafir, menimbulkan perpecahan dalam tubuh Khawarij. Munculnya kelompok ekstrem dalam khawarij, tidak hanya menuduh kafir orangorang yang tidak menjalankan hukum Allah, namun mereka juga menggolongkan pelaku dosa besar (al-murtakib al-kaba>ir) sebagai kafir. Dari persoalan dosa besar tersebut, kemudian tumbuh dan berkembanglah diskursus-diskursus teologi Islam.

Menyikapi status pelaku dosa besar, muncul tiga aliran utama kalam. Pertama, Khawarij, kelompok ini berpendapat pelaku dosa besar adalah kafir. Kedua, Murji'ah, kelompok ini berpandangan bahwa pelaku dosa besar tetap mu'min bukan kafir,

${ }^{18}$ Lihat, Abdullah saeed, Islamic Thought an Introduction..., hlm.61 terkait dosa yang dilakukan maka itu hak Allah untuk mengampuni atau tidak. Ketiga, Mu'tazilah, kelompok terakhir ini menolak kedua pendapat kelompok di atas, bagi mereka pelaku dosa besar tidak mukmin dan tidak pula kafir (al-manzilah baina manzilatain). Kemudian, muncul pula sekte-sekte semisal Qadariyah, Jabariyah, Asy'ariyah, Maturidiyah dan Syi'ah.

Dari konteks sosio-politik di atas, kemudian diskusrus kalam berkembang pesat. Masing-masing school of Theology (sekte kalam) memiliki konsep yang berbeda-beda. Isu-isu seputar diskursus kalam yang berkembang saat itu adalah tentang tauhid; wujud, keesaan, sifat tuhan, pengetahuan tuhan, keadilan tuhan, status pelaku dosa besar, hari akhir (eskatologis). Pada perkembangan selanjutnya, muncul kitab-kitab ilmu kalam, dengan berbagai formula yang membahas segala sesuatu tentang tuhan dan eskatologis, sehinga kalam menjadi satu disipilin ilmu mandiri dalam Islam. Yang perlu dicacat dari refleksi sejarah di atas adalah bahwa kalam merupakan hasil interpretasi nalar manusia atas wahyu Tuhan, sebagai respon dalam menyikapi zaman (konteks politik saat itu). Pemahman ini, akan membawa kita pada kesimpulan bahwa kalam adalah produk penfasiran manusia terhadap wahyu tuhan, maka kalam adalah "diskursus" bukan ilmu yang suci dan mutlak, tidak kebal kritik, oleh karena itu maka Ilmu kalam atau teologi dapat direformulasi sesuai kebutuhan zaman dan demi kemaslahatan ummat Islam dan manusia.

\section{Rethingking Kalam}

Rethinking kalam merupakan ikhtiar untuk melakukan pembaruan dan transformasi dari pandangan kalam klasik ke "teologi sosial" dalam konteks multiculturalism. Permasalahanpermasalahan baru -yang menjadi anomali- 
di era pluralisme dan multikulturalisme, meniscayakan perlunya "shifting paradigm" dalam bidang kalam. karena persoalan kontemporer tidak bisa didekati dengan sudut pandang klasik yang dogmatisabstrak an sich. Tetapi membutuhkan formulasi teologi yang membumi, inklusive, transformatif dan bersifat dialogis.

Pada bagian ini, penulis akan memaparkan kritik para pemikir Muslim terhadap corak kalam klasik (teologi), dan keharusan untuk melakukan pembaruan sebagai sebuah kebutuhan. Kritik terhadap corak ilmu kalam, sejak awal telah dimulai oleh al-Ghazali dan Ibnu Rusyd. Kemudian dalam konteks modern, muncul pemikirpemikir semisal Muhammad Iqbal, Muhammad Abduh, Fazlurrahman, Hasan Hanafi, Abdul Karim Soroush, yang mengkritik kalam untuk direformulasi dan keluar dari kebekuan "diskursus" kalam klasik yang dinilai sudah tidak tepat dikembangkan dalam dunia kontemporer.

\section{a. Kritik Atas Paradigma kalam klasik}

Perdebatan tentang defenisi kalam atau teologi di kalangan ummat Islam (terutama Indonesia) masih berkutat pada level semantik. Perdebatan itu setidaknya menghadirkan dua pandangan besar. Pertama, kelompok yang memiliki background keilmuan tradisional, mengidentikan teologi sebagai Ilmu kalam; yakni suatu disiplin ilmu yang mempelajari ilmu ketuhahan yang bersifat abstrakmetafisis dan skolastik. Kedua, kelompok yang pernah mengenyam pendidikan tardisonal, kemudian terdidik dalam tradisi akademik Barat, mempelajari Islam dari studi-studi akademik-modern, lebih melihat teologi sebagai penafsiran terhadap realitas dalam persfektif ketuhanan. ${ }^{20}$

${ }^{20}$ Kuntowijoyo, Paradigma Islam, (Bandung : Mizan, 2008) hlm.478
Sistematisasi kalam klasik memiliki tiga tema pokok; Uluhiyah (ketuhanan), Nubuwwah (kenabian) dan Ma'ad (eskatologi). Nyaris seluruh perdebatan dalam wacana kalam klasik berputar pada tiga hal tersebut. bersifat teoritis, abstrak dan intelektual. Dalam perkembangan selanjutnya, ketika Islam mulai mengalami "encounter" dengan berbagai tradisi keagamaan lain, para mutakallimun mulai mengembangkan argument teologi Islam untuk merespon tantangan dari tiga tradisi besar pra-Islam; Zoraostrianism, Yahudi and Kristen.

Dalam kondisi itu, ilmu kalam dalam bangunan pemikiran Islam klasik menjadi sangat sentral, bahkan nyaris seluruh problem keagamaan selalu diukur dan dilihat dari sudut pandang llmu kalam ${ }^{21}$. fakta bahwa ilmu kalam lahir dari narasi sosio-historis dan konteks politik tertentu menjadi kabur dan nyaris terlupakan. Ilmu kalam dianggap sakral dan mutlak, dan a historis. Pada tahapan ini, maka ummat Islam cenderung melakukan apa yang disebut Muhammad Arkoun sebagai proses "Pensakralan pemikiran keagamaan" (Taqdis al-afka $>r$ ad-di>ni $>)^{22}$ atau meminjam bahasa Fazlurahman disebut dengan ortodoksi. ${ }^{23}$

Dalam narasi sejarah, Ilmu kalam mulai dibakukan sebagai disiplin ilmu mandiri pada masa pemerintahan Khalifah alMa'mun (memerintah 813-833 M), dipelopori oleh kaum Mu'tazilah dengan mengadopsi filsafat Yunani kemudian

${ }^{21}$ Lihat Amin Abdullah, Falsafah Kalam Modern (Yogyakarta : Pustaka Pelajar, 2009) hlm.v

${ }^{22}$ Mohammad Arkoun, al-Isla $>m$ : al-Akhla $>q$ wa al-siya $>$ sah, terj Hasyim Salih, (Beirut ,1986) hlm.118

${ }^{23}$ Fazlurrahman, Islam terj. Ahsin Muhammad, (Bandung : Pustaka Salman, 1990) HIm.349 
dipadukan dengan logika kalam. ${ }^{24}$ tetapi, kalam sebagai "diskursus" telah digunakan sejak lama oleh Hasan al-Basri (642-728 M) dalam konteks perdebatan antara Qadariyah dan Jabariyah tentang kebebasan manusia dan taqdir. ${ }^{25}$ Perdebatan itu jika dirunut ke belakang adalah produk dari konflik terkait khilafah.

Adanya relasi kalam dan filsafat Yunani bisa dibuktikan dengan melihat model argumen-argumen rasional yang dibangun oleh para mutakallimun. Metode rasional yang digunakan sangat mirip dengan model logika para filosof Yunani mazhab Stoic. Melalui penelitanya, Jossef Van Ess menjelaskan bahwa metode para mutakallimun dalam beragumen yang menekankan pada model defense (bertahan) dan attack (menyerang), menggambarkan bahwa logika yang digunakan lebih condong pada pola apologetik dan agresif ${ }^{26}$. Singkatnya, bahwa logika kalam yang digunakan para mutakallimun bersifat argumentum ad hominem model mazhab stoic. 27

Menurut Osman Bakar, teologi dan filsafat sama-sama menggunkan metode silogisme dalam aturan berfikirnya; suatu metode pengambilan kesimpulan atau pengetahuan berdasarkan atas peremispresmis, baik premis mayor ataupun premis minor. Namun ada sedikit perbedaan diantara keduanya, dalam disiplin filsafat, pengetahuan yang bisa dijadikan premis mayor harus benar-benar merupakan premis primer, premis yang benar, pasti dan meyakinkan setelah diuji secara rasional. Sedangkan dalam disiplin teologi,

\footnotetext{
${ }^{24}$ A. Hanafi, Pengantar Theology Islam (Jakarta : Jayamurni, 1947), hlm.14

${ }^{25}$ Nurcholis Madjid, Islam Kemodernan dan Keindonesiaan, (Bandung: Mizan, 199) hlm. 279

${ }^{26}$ Amin Abdullah, Falsafah...,hlm.4

${ }^{27}$ Argumentum ed Hominem adalah seni berdebat yang bertujuan untuk mencari menang, bukan mencari kebenaran.
}

premis mayor dapat diambil dari sesuatu yang sudah diterima secara umum "common senses" dalam masyarakat atau berdasarkan keyakinan yang diperoleh dalam normatifitas ajaran agama. ${ }^{28}$

Proses kanonisasi diskursus-diskursus kalam kedalam kitab-kitab merupakan upaya pembangunan citra "epistemolgi kalam" menuju level kemapanan. ${ }^{29}$ Terbukti belakangan, kalam menjadi suatu tema sentral yang mewarnai khazanah pemikiran Islam selama berabad-abad. kalam yang pada awalnya adalah hasil perdebatan, pergumulan dan penafsiran para mutakallimun atas wahyu Tuhan, kemudian menjadi ajaran baku yang bersifat doktriner. Terlebih lagi ketika wacana kalam didominasi oleh ajaran Ahl as-sunnah wa al-jama>'ah ${ }^{30}$, kalam seolah-olah diperlakukan sebagai ajaran "normatif wahyu", ia menjadi taken for granted dan undebatable.

Wacana kalam klasik bersifat teosentris dan cenderung deduktif-spekulatif. tematemanya selalu mengawang-ngawang, abstrak, dan jarang landing ke bumi. Akibatnya, kalam klasik tidak peka terhadap persoalan sosial ummat dan persoalan kemanusiaan universal. Fakta inilah yang menjadi titik kritik Muhammad Iqbal, menurutnya, studi terhadap al-Qur'an dan aliran pemikiran kalam klasik yang dipengaruhi filsafat Yunani,

28Lihat Osman Bakara, Hierarki Ilmu (Bandung : Mizan, 1997) hlm 105-106

${ }^{29}$ Kuntowijoyo, Islam Sebagai Ilmu (Yogyakarta : Tiara Wacana, 2006) hlm.12

${ }^{30}$ Bahkan salah seorang tokoh terkemuka NU, Kiyai Said Aqil siradj, mengkritik warisan doktrinal ahl- as-sunnah wa al-jamas'ah di lingkungan NU yang dinilainya statis dan beku, terutama paradigma Asy'ariyah yang menurutnya pro Status Quo dan menghindari krtik terhadap kekuasaan. Lihat Ahmad Baso, Posmodernisme sebagai kritik Islam :Kontribusi metodologi 'Kritik Nalar"' Muhammad Abed al-Jabiri, (Yogyakarta : LKIs, 2000) hlm. X. 
memperlihatkan dengan jelas bahwa meskipun filsafat telah memberikan sumbangan yang besar dalam perkembangan para pemikir muslim, namun hal itu telah mengaburkan visi mereka (ilmuan muslim) terhadap alQur'an. ${ }^{31}$ sebagai contoh apa yang disebut dengan kekaburan visi pemikir Islam terhadap al-Qur'an, Iqbal mencontohkan bahwa dikursus kalam Asy'ariyah menggunakan filsafat dialektika Yunani untuk mempertahankan ortodoksinya. Sedangkan Mu'tazilah, terlalu jauh menggunakan akal, sehingga mereka tidak menyadari bahwa pemisahan antara pemikiran keagamaan dan pengalaman kongkrit manusia dalam wilayah pengetahuan agama merupakan sebuah kesalahan besar. ${ }^{32}$

Jauh sebelum kritik Iqbal, al-Ghazali juga melakukan kritik terhadap ilmu kalam, karena menemukan anomali-anomali dalam disiplin tersebut. Al-Ghazali dengan sangat cerdas mengoreksi detil-detil kelemahan ilmu kalam. sehingga ia sampai pada kesimpulan, bahwa ilmu kalam tidak mampu mendekatkan manusia kepada tuhan. ${ }^{33}$ bahkan dalam salah satu karyanya ilja $>m$ al-awwa>m 'an 'ilmi al-Kala $>m$, Ghazali mengkritik habis-habisan ilmu kalam dengan metode penalarnya yang berbelit-belit, sehingga dikhawatirkan akan berdampak negatif bagi masyarakat awam. ${ }^{34}$ Tetapi kemudian sangat disayangkan, al-Gazali juga pada akhirnya terjebak dalam lingkaran kalam, ia bahkan

${ }^{31}$ Lihat Muhammad Iqbal, The Reconstruction of Religious Thought in Islam, (Lahore : 1975) hlm.3 hlm. 4

32Muhammad Iqbal, The Reconstruction..., hlm. 16-17

${ }^{33}$ Lihat al-Ghazali, al-Munqidz min al-dala $>$ l,

${ }^{34} \mathrm{Al}-\mathrm{Ghazali}$, Iljam al-'Awwam an Ilmi alKala $>$ m, (Beirut : Dar al-Kitab al-Arabi, 1985) hlm. 81 menjadi juru bicara teologi Asy'ariyah. Pemikiran kalam Asy-'ariyah merupakan salah satu sekte yang mendominasi pemikiran Islam, hal ini tentunya tidak bisa dilepasakan dari peran dari tokoh-tokoh besar di bidang fiqih semisal Imam Maliki dan Syafi'i yang secara teologis berkiblat ke Asy'ari. Sedangkan Imam Hanafi lebih dekat ke teologi Maturidiyah, dan Syiah Imamiyah dan zaidiyah mewarisi teologi rasionalnya Mu'tazilah. ${ }^{35}$

Ibnu Rusyd juga tak ketinggalan mengkritik paradigma kalam klasik, menurutnya ta'wil-ta'wil yang dilakukan oleh Mu'tazilah dan Asy'ariyah telah memecah belah ummat Islam. bahkan secara metodolgis, Ibnu Rusyd mengkritik ilmu kalam, karena belum mampu menggunkan metode demonstratif (Burhani), terutama dalam hal ini kalam Asy'ariyah. ${ }^{36}$ Berangkat dari kritik Ibnu Rusyd, penulis melihat bahwa anomali dalam diskursus kalam klasik adalah memunculkan perpecahan internal ummat Islam. Maka dalam kehidupan kontemporer yang plural dan multikultural konsepsi kalam klasik sudah tidak bisa dipertahankan lagi. terlebih dewasa ini, sebagai masyarakat dunia, ummat Islam berada dalam lingkaran agama-agama, kepercayaan, ideologi, dan berbagai "ismeisme" lainya.

selanjuntnya kritik atas teologi Islam dikemukan oleh seorang pemikir Mesir, Hassan Hanafi. Menurutnya, teologi Islam harus diperbaharui, karna sifatnya yang terlalu abstrak-dogmatis dan kurang membumi. Ia menawarkan teologi sebagai ilmu tentang perjuangan sosial, menjadikan keimanan berfungsi secara aktual sebagai landasan etik dan motivasi tindakan

${ }^{35}$ Abdullah Saeed, Islamic Thought.., hlm. 71

36Ibnu Rusyd, Fasl al-Maqa>l fi ma> bain alHikmah wa Asy Syaari'ah min al-Ittisa>l. (Mesir: Dar al-Ma'arif, t.t,) hlm. 63 
manusia. karena itu, ia mengusulkan untuk mentransformasi teologi Islam yang bersifat tradisional-teosentris menuju teologi antroposentris; dari tuhan kepada manusia (bumi), dari tekstual menuju kontekstual (min al-nash ila al-wa>qi'), dari teori kepada tindakan, dari takdir menuju kehendak bebas. Menurut Hanafi, pembaharuan ilmu kalam memiliki dua lasan; pertama, kebutuhan akan adanya sebuah teologi yang jelas di tengah pertarungan global antara berbagai ideologi. Kedua, pentingnya teologi baru yang bukan hanya bersifat teoritis, namun lebih praksis yang bisa mewujudkan gerakan dalam sejarah. ${ }^{37}$

Dalam konteks modern, ummat Islam dituntut mampu dan harus berani mereformulasi pandangan kalam klasik. upaya reformulasi bukanlah tindakan dosa atau melanggar normatifitas agama. Karena menurut Amin Abdullah, Ilmu kalam adalah tidak lain dan tidak bukan, merupakan sebuah rumusan sistematis keprihatinan dan pergumulan pemikiran manusia tentang persoalan-persoalan ketuhanan yang terjadi pada era tertentu dan penggal sejarah tertentu. meskipun sumber utama ilmu kalam adalah "wahyu" namun konsepsi rumusan, pemikiran dan rancang bangun epistemologi keilmuanya adalah hasil kreasi manusia semata. ${ }^{38}$ Jika mengancu pada pendapat Amin Abdullah, maka ilmu kalam adalah ilmu yang dihasilkan oleh kreatifitas nalar manusia, bukan sesuatu yang mutlak dan datang dari langit. Dengan demikian, formulasiformulasi kalam bukanlah sesuatu yang baku, ia dapat berubah seiring dengan

${ }^{37} \mathrm{AH}$. Ridwan, Reformasi Intelektual Islam, (Yogyakarta : Ittaqa Press, 1998) hlm. 44-45

${ }^{38}$ Amin Abdullah, Islamic Studies di Perguruan Tinggi : Pendekatan integrativeinterkonektif, (Yogyakarta: Pustaka Pelajar. 2006) hlm. 319 perkembangan zaman dan kebutuhan serta tantangan manusia dalam kehidupanya.

Maka dari itu, di era pluralisme dan multicultarlisme, merupakan sebuah keharusan bagi ummat Islam untuk menggeser pandangan kalam klasik yang bersifat abstark-dogmatis dan sektarianeksklusif, menuju teologi sosial yang dialogis dan inkslusif. Mengingat ummat Islam saat ini, telah tersebar dalam bingkai negara-negara bangsa dan hidup secara besama-sama dengan komunitas agama lain. Yang harus dilakukan adalah menggembangan teologi sosial untuk menciptakan harmoni dalam common good dalam sistem sosial masyarakat modern.

\section{b. Dari Kalam Klasik Menuju Teologi Sosial}

Langkah pembaruan kalam adalah dengan melakukan "Shifting paradigm" dari paradigma kalam klasik menuju teologi sosial; sebagai new paradigm. Karena ummat Islam dewasa ini, telah menjadi penduduk global dalam era multikultural. Selain itu, terbentuknya negara bangsa telah menyebabkan ummat Islam terpisahpisah ke dalam berbagai wilayah teritorial negara. Di dalam negara tersebut ummat Islam harus hidup secara bersama-sama dengan komunitas agama lain. Maka Sikap inklusif dan etika sosial mutlak dibutuhkan untuk menciptakan harmoni.

Paradigma teologi sosial pertama-tama harus disandarkan pada pemahaman atas al-Qur'an sebagai paradigma. Pengertian paradigma dalam hal ini mengacu pada pengertian yang dibangun oleh Thomas Kuhn, bahwa pada dasarnya realitas sosial dikonstruksi oleh mode of thought yang pada akhirnya menghasilkan mode of knowing. Dalam pengertian ini, paradigma al-Qur'an adalah suatu model konstruksi pengetahuan yang memungkinkan manusia memahami 
sebagaimana al-Qur'an memahami realitas berdasarkan worldview-nya. ${ }^{39}$

Beragkat dari pengertian dari pengertian di atas, , maka paradigma mengandung beberapa unsur yaitu; sebagai pandangan mendasar yang disepakati sekelompok ilmuwan; mutakallimun. Objek ilmu pengetahuan yang seharusnya dipelajari oleh suatu disiplin (baca; ilmu kalam). Metode kerja ilmiah (logika-red) yang digunakan untuk mempelajari objek penelitian(baca; konsep-konsep ketuhanan dan eskatologis). Konsep paradigma tersebut bisa disejajarkan dengan asumsi dasar atau paraduga Ala Gadamer, serta struktur kognitif fundamental ala Michel Focault 40

Teologi sosial sebetulnya memiliki basis epistemologinya dalam al-Qur'an. terkait dengan hal itu, kiranya penulis tertarik untuk meminjam pandangan Kuntowijoyo mengenai klasifikasi ilmu di dalam al-Qur'an. Menurut Kuntowijoyo41, al-Qur'an menjelaskan ada dua kategori ilmu; yaitu ilmu mengenai cakrawala (' $a>f a>q)$ dan ilmu mengenai manusia itu sendiri atau humaniora (anfusihim). Hal ini dijelaskan dalam QS Fushilat : 53.

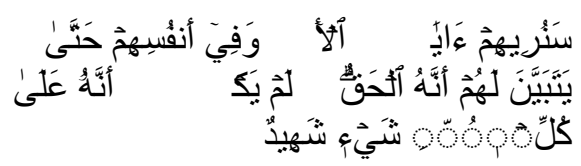

Kami akan memperlihatkan kepada mereka tanda-tanda kekuasaan kami di segenap ufuk (jagat raya) dan pada diri mereka sendiri...

Dalam menjelaskan ayat di atas, Kuntowijoyo menekankan pada pemaknaan

\footnotetext{
${ }^{39}$ Kuntowijoyo, Pengilmuan Islam...,hlm.11

${ }^{40}$ Lebih lanjut lihat Bambang Sugiharto, Postmodernisme tantangan bagi filsafat, (Yogyakarta : kanisius, 1996) hlm. 92

41Kuntowijoyo, Pardigma Islam... hlm.262
}

kata-kata 'anfusihim sebagai deskripsi alQur'an tentang ilmu kemanusiaan atau yang sering disebut humaniora. dalam konteks ini, penulis memahami humaniora sebagai ilmu yang terus berdialektika dengan perkembangan dan kemajuan zaman. Maka akan selalu terjadi pemaknaan secara terus menerus, karena adanya perubahan struktur dan ruang dalam kehidupan manusia. Diskursus kalam atau teologi bisa dikategorikan sebagai "ilmu" bersifat sosialhistoris (humaniora), meskipun ia bersumber pada wahyu. karena kalam lahir dari pergumulan masyarakat muslim awal atas problemnya saat itu (politik-red) yang kemudian menghasilkan model penafsiran tertentu. Dari pemahaman itu, maka teologi sosial sebagai kategori ilmu "anfusihim" merupakan cara bagaimana manusia memahami dan merespon konteks sosialnya, demi mewujudkan manisfestasimanisfestasi ketuhanan di muka bumi.

Di era modern dan posmodern ini, teologi yang hanya berkutat pada persoalan ketuhanan semata (teosentris) dan tidak mengaitkan diskursusnya pada persoalanpersoalan kemanusiaan universal, lambat laun akan menjadi out of date. Sebab, teologi yang berkutat pada persoalalan abstrak dan skolastik akan kehilangan relevansi sosial dengan tantangantantangan kekinian; kemanusiaan, pluralisme agama, kemiskinan struktural, kerusakan lingkungan dan lain-lain. ${ }^{42}$

Terma "teologi sosial" dalam tulisan ini, dimaksudkan sebagai pandangan baru dalam ranah teologis yang bersifat antroposentris, terbuka dan dialogis. sehingga dimensi teologis benar-benar hidup dalam keseharian masyarakat dan tidak terkesan melulu soal abstrakmetafisis. Teologi sosial lebih fokus pada

${ }^{42}$ Amin Abdullah, Falsafah Kalam di Era Postmodernisme (Yogyakarta: Pustaka 
tantangan riil yang dihadapi oleh ummat beragama dalam dunia dan peradaban kontemporer.

Fenomena

pluralitas

dan

multikulturalitas yang kian pesat, menuntut ummat Islam untuk mereformulasi pandangan-pandangan kalam klasik yang cenderung apalogistik, menjadi pandangan yang bersifat dialogis dan inklusif. Karena dalam bingkai globalisasi, ummat Islam telah menjadi warga negara global (global citizenship). Disinilah tantangan umat beragama saat ini, ummat Islam harus mampu mendialogkan 'agama yang tidak berubah' dengan 'dinamika sosial yang terus berubah'. Dengan demikian Ummat Islam harus melakukan shifting paradigm untuk menemukan konsepsi keagamaan yang mampu menjawab tantangan perubahan zaman dan perubahan interpretasi umat atas zaman. Hal ini tidak dilakukan dengan mengubah teks-teks keagamaan, melainkan dengan mengartikukasikan semangat beragama yang inheren dengan narasi zaman.

Gagasan teologi sosial berpijak pada dua hal; Pertama, sistematisasi kalam klasik sudah terlalu lama mewarnai pemikiran Islam, ketika munculnya anomali-anomali baru dalam kehidupan beragama, maka menjadi keharusan untuk melakukan pembaruan dan membersihkan diskursus kalam dari model argumen yang eksklusif dan sekatarian, karena metode tersebut sudah tidak relevan lagi untuk dikembangkan di era multikulturalisme. Kedua, wacana kalam yang dogmatisabstrak an sich, harus dipikir ulang dan direformulasi. para teolog dituntut untuk memasukan dimensi praksis sebagai pembaruan dalam studi-studi kalam. dimensi praksis yang dimaksud adalah ilmu kalam harus menyentuh berbagai problem kemanusiaan kontemporer seperti isu pluralisme agama, krisis multikulturalisme, persoalan kemiskinan, persoalan korupsi dan lain-lain.

Teologi sosial menekankan pentingnya dialog dan toleransi, bukan debat yang bersifat argumentum ad hominem; mencari menang kalah, untuk menunjukan superioritas dan sektarianistik. Karena model berfikir kalam klasik yang seperti itu, tidak bisa memberikan kontribusi bagi peradaban modern. hal ini, kemudian menginspirasi Fethullah Gulen untuk mempromosikan 'dialog antar-peradaban' sebagai counter discoruse atas konsepsi simplistis Samuel Huntington tentang Clash of Civilizations. Senada dengan Gulen, Abdul Karim Soroush juga mendukung pentingnya dialog antar peradaban, ia berpendapat bahwa tidak ada konsepsi agama yang 'murni'. Teks-teks agama sifatnya memang tidak berubah. Namun, interpretasi dan artikulasi atas teks tersebut dinamis, karena manusia hidup dalam realitas sosial yang selalu berubah (al-nushu>h mutanahiyah wa al-waqa>i' gairu mutanahiyah). Dengan cara pandang seperti ini, umat beragama perlu menghentikan praktik beragama yang mengklaim kebenaran, karena praktik beragama pada dasarnya tidak hanya bersifat 'penuh penalaran', tetapi juga aspek 'reflektif'.

Untuk mewujudkan dan mengembangkan teologi sosial, dibutuhkan kesadaran akan pentingya objektifikasi. Ketika masyarakat semakin plural, terlebih dalam ruang negara bangsa, maka ummat Islam harus menerima pluralisme sebagai konsekuensi logis dari kehidupan berbangsa. Perjalanan hidup umat Islam dalam beragama tidak harus hanya didominasi oleh interpretasi kalam dan fiqh yang stagnan, tetapi penting juga melibatkan pengalaman praksis beragama dalam realitas masyarakat multikultural. Konsekuensinya, praktik beragama dalam bentuk interaksi, yang mana di dalamnya 
kita harus berbuat baik kepada sesama manusia sebagai manifestasi dari "iman" dan "amal saleh". sehingga pengalamanpengalaman empiris inilah yang membuat penalaran dalam beragama menjadi dinamis.

Sense beragama secara 'dialogis' inilah yang menurut penulis merupakan bentuk "teologi sosial", hal ini perlu dikembangkan dalam konteks hubungan antar agama maupun intra agama; seperti relasi MuslimKristen dalam konteks negara, relasi SunniSyiah dalam internal dunia Islam, bahkan relasi dengan gologan-golangan minoritas seperti Ahmadiyah, Bahai, sunda wiwitan dan lain-lain. Terkadang, persolan MuslimKristen terlalu jauh diseret pada kepentingan politik praktis tertentu (politisasi agama), pun demikan persoalan Sunni dan Syiah.

\section{E. Aspek Pemikiran 'Teologi Sosial' Fethullah Gulen}

Pada bagian ini, penulis akan mendeskripsikan pemikiran "teologi sosial" Fethullah Gulen dan bagaimana kontribusinya dalam merespon isu multikultarlisme. Terma "teologi sosial" sesunghunya bukanlah sebuah klaim dari Fethullah Gulen untuk mengidentifikasi pemikiranya. Namun, penulis menggunakan terma tersebut sebagai sebuah cara untuk memberikan "ciri" dari konsep teologi Gulen, yang lahir dari perenungan dan refleksi atas kenyataan dan tantangan yang dihadapi manusia. dan sebagai respon terhadap realitas multikultaral dewasa ini. Dengan menumbuhkan kesadaran untuk mendukung dialog intereligious dan intercultural dengan mengedepankan humanisme dan altruisme.

Konstruksi pemikiran teologi sosial Gulen, banyak dipengaruhi oleh tokohtokoh yang hidup pada periode akhir menjelang keruntuhan Turki Ustmani. diantaranya; Said Nursi dan Muhammad Hamdi Yazir. Melalui karya-karyanya, Dua tokoh ini sangat mempengaruhi pemikiranpemikiran Gulen. Secara khusus, Said Nursi memiliki peran signifikan dalam perkembangan pemikiran Gulen, terutama melalui karyanya "Risale-i Nur". Selain itu, ia juga banyak dipengaruhi oleh sufi-sufi awal, yakni dua tokoh besar; Ibnu Arabi dan Jalaluddin Rumi. Beberapa poin pemikiran Fethullah Gulen yang akan penulis sajikan disini adalah ; Tauhid berdasarkan cinta dan humanisme, Al-Qur'an Nabi Muhammad dan sense of multiculturalisme, tentang Islam dan demokrasi dan Aktvisme sosial : Hizmet, Pendidikan dan multikulturalisme.

\section{a. Tauhid berdasarkan Cinta dan Humanisme}

Selama ini, konsep tauhid dipahami hanya semat-mata soal metafisis, abstrak dan dogmatis. tauhid jarang dilihat dari perspektif sosial-kemanusiaan (antroposentris). Sehingga konsep tauhid bersifat abstrak-spekulatif an sich, tidak pernah menyentuh dimensi realitasempirik dari dialektika kehidupan ummat beragama yang terus berkembang. Sehinggga tauhid kehilangan visi teologis dalam menyelesaikan problem peradaban modern.

Sebagai seorang Teolog yang memiliki latar belakang sufistik, Gulen membangun konsep tahuhid yang agak berbeda, pandanganya tentang tauhid banyak diinspirasi oleh nilai-nilai tasawuf. Dalam memperkokoh konsep tauhidnya Gulen mendasarkanya pada al-hub (cinta); yaitu cinta pada Tuhan dan cinta pada sesama manusia. Cinta menurutnya merupakan elemen paling penting dalam kehidupan manusia. nyaris semua eksistensi dan esensi di dunia ini membutuhkan cinta. Tuhan pun menciptakan jagad raya ini 
dengan cinta. ${ }^{43}$ Manifestasi dari konsep cinta pada tuhan adalah cinta terhadap sesama manusia. karena mencintai tuhan berarti harus mencintai pula ciptaanya. pandangan ini tauhid inilah yang dimaksudkan penulis sebagai aplikasi praksis "teologi sosial". teologi tidak semata soal relasi vertikal, namun juga relasi horisontal yang dibangun atas dasar nilanilai ketuhanan, yaitu cinta (rahman dan rahim).

Dewasa ini, Teologi sosial menjadi sangat urgen dikembangkan dalam konteks multikulturalisme, demi terciptanya integrasi sosial. karena multikulturalitas sering menjadi problem dalam kehidupan manusia. banyak terjadi konflik disebabkan oleh kegagalan memahami multikulturalistas sebagai sebuah keniscayaan sejarah dan ketetapan tuhan. Multikulturalitas disebabkan oleh Tuhan sendiri, ia sendiri yang menghendaki dan menciptakan keragaman tersebut. Oleh karena itu, sepantasnya manusia menyikapi Keragamaan sebagai anugerah. Terkait dengan persolan tersebut, kiranya penting mengutip pendapat Ibnu Arabi :

God Himslef is the first problem of diversity that has become manifset in the cosmos. The fist thing that each existent thing looks upon is the cause of its own existence. In itself each thing knows that it was not, and then it then came to be through temporal origination. However, in this coming to be, the dispotions of the existent things are diverse. Hence they have diverse opinion about identity of causes that brought them into existence. Therefore

${ }^{43}$ Fethullah Gulen, Toward Global Civilization; Love and Tolerance, (New Jersey : Light, 2004) hlm.1 the real is the first problem of diversity in the cosmos. 44

Jika statemen Ibnu Arabi di atas direnungkan secara mendalam, maka multikulturalisme seharusnya tak banyak mendatangkan masalah. Karena hakikatnya adalah dari sang pencipta sendiri. Tetapi nalar sebagian kelompok belum menyadari hal tersebut. keragaman agama, budaya, bahasa, ras dan lain-lain, seringkali menjadi alasan pemicu konflik. Terlebih ketika berbicara pluralitas agama, hal tersebut menjadi faktor yang paling rawan dan dominan memunculakn konflik". Konflik agama, biasanya berangkat dari perdebatan teologis, menyangkut esensi dan sifat "Tuhan" yang diyakni dalam persfekti agama masing-masing. Dengan latar belakang keyakinan yang berbeda, satu sama lain terkadang saling mencaci konsep sesembahan. Gulen tidak membenarkan tindakan ummat beragama yang saling memperolok seperti itu, ia bahkan menentang sikap seperti itu, ia membangun argumenya berdasarkan surat al-an'am ayat 108 :

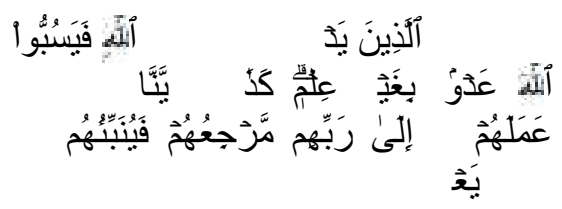

Dan janganlah kamu mencaci maki sesembahan mereka selain Allah, karna mereka juga akan memaki Allah dengan melampui batas tanpa pengetahuan. Demikianlah kami jadikan setiap ummat menganggap baik pekerjaan mereka, kemudian kepada tuhanlah mereka akan kembali, lalu Dia (Tuhan) akan

${ }^{44}$ Ibnu Araby, al-Futu>ha>t al-Makkiyah, Mahmu>d Matraji> (ed), 8 volume (beirut: Da>r alFikr, 2002) vol. VI hlm. 303 
memberitakan apa yang telah mereka kerjakan (QS al-An'am (6): 108)

Ayat di atas dengan sangat gamblang menjelaskan tentang larangan perdebatan teologis yang berlebihan. Yaitu perdebatan yang berujung pada sikap saling mencacimaki sesembahan. ibroh yang bisa diambil dari ayat di atas adalah tidak boleh suatu ummat menghina keyakinan teologis ummat lainya. Larangan ini bertujuan untuk menghindari konflik antar ummat beragama, karena ketika suatu ummat menghina konsep teologi ummt pemeluk agama lain, maka kelompok tersebut akan berbalik menghina konsep teologi Islam.

Perdebatan teologis semacam ini, harus dihindari dan digeser pada penafsiran tauhid yang bersifat praksis untuk membangun relasi damai antar agama. sehingga agama benar-benar hadir untuk kemanusiaan. Bukan hanya mengawangngawang di angkasa. Karena semua agama datang dengan semangat cinta, kasih dan keadilan sosial. maka, sebagai khalifah di muka bumi, manusia memiliki tanggung jawab untuk mewujudkan kemaslahatan di muka bumi. Oleh sebab itu, agama tidak boleh berhenti dan hanya berkutat pada soal teologi (Baca: abstrak) an sich, melainkan perlu mengambil peran secara sosial, sebagai teologi antroposentris.

Maulana Kalam Azad berpendapat, teologi tidak akan berjalan tanpa berpijak pada konteks kehidupan yang terus berubah sebagai wujud kreatifitas tuhan. Oleh karena itu, pencari kebenaran tentang tuhan akan dihadapkan pada realitas keagungan ciptaan tuhan yang terus berubah-ubah. ${ }^{45}$ Maka, teologi bersifat normatif dan kontesktual. Kontekstualitas

${ }^{45}$ Lihat, Maulana Kalam Azad dalam Asghar Ali enginer, Islam dan Teologi Pembebasan, (Yogyakarta : Pustaka Pelajar, 1999) hlm. 186-187. inilah yang menjadikan ayat-ayat tuhan selalu relevan dalam setiap waktu dan tempat. Disinilah pentingnya melakukan upaya interpretasi kontekstual sebagaimana yang disarankan Fazlurrahman, yakni dengan cara memahami kondisis sosila-budaya kekinian dan mengaitkanya dengan tradisi Nabi secara khusus dan tradisi masyarakat Arab secara umum. Dengan cara demikian, akan diperoleh makna ayat yang subtantif atau disebut dengan ideal-moral. Kontektualisasi tersebut bisa dikembangkan dalam setiap ruang budaya dimana ummat Islam itu hidup.

Perdebatan teologis yang alot dan bersifat defense dan attack, telah mengakibatkan carut-marutnya hubungan antar agama. Maka dari itu, kontekstualisasi teologi mutlak dibutuhkan ke arah yang lebih inklusif dan dialogis. Di atas semua upaya kontekstualisasi itu, hal yang paling penting dimiliki ummat manusia adalah rasa empati dan cinta. Keragaman agama dan budaya harus dipandang sebagai rahmat. sebisa mungkin, semua perbedaan harus disikapi dengan cinta. Karena, hanya dengan cinta persoalan bisa diselesaikan secara damai. Keragaman harus dipandang dalam persfektif cinta, Karena cinta kita "berada" dan dengan cinta kita "mengada", dan hakikat segala eksistensi (agama dan budaya) di dunia ini adalah cinta. hal ini sebagaimana diungkapakn Gulen :

Love is the reason for existence and its essence, and it is the strongest tie that binds creatures together. Everything in the universe is the handiwork of God. Thus, if you do not approach humanity, a creation of God, with 


\section{love, then you have hurt those who love God and God loves. 46}

Jika semua wujud yang ada di dunia ini hadir karena cinta, maka tak ada alasan untuk saling membenci. Segala sesuatu di dunia ini adalah kreasi "tangan" Tuhan. Maka dari itu dekatilah semua mahluk dengan cinta, karena jika tidak memperlakukan mereka secara manusiawi, itu artinya kita telah melukai mahluk sebagai ciptaan tuhan, mahluk yang mencitai tuhan dan tuhanpun mencintai mereka.

Dalam kamus kemanusiaan, cinta itu tidak lain adalah hidup itu sendiri. manusia seharusnya memiliki rasa saling mencintai. Tuhan tak pernah menciptakan suatu relasi yang paling kokoh melebihi relasi yang dibangun atas dasar cinta. Cinta itulah yang menjadi rantai pengikat antar manusia tanpa harus memandang sekat-sekat apapun, termasuk agama. Karena segala perbedaan baik agama, budaya, ras dan seterusnya adalah bersumber dari sang pencipta. ${ }^{47}$

Persoalan

$$
\text { pluralitas }
$$

dan

multikulturalitas di era globalisasi, sering menyebabkan muramnya nila-nilai kemanusiaan dan hilangnya sikap toleransi. Ada kelompok-kelompok tertentu yang ingin menyeragamkan kecenderungan, ideologi dan keyakinan manusia. Ketika ada kelompok lain berbeda denga mereka, maka kelompok tersebut dianggap menyimpang, sesat dan harus diberangus. Menurut Gulen, seorang muslim yang penuh cinta, dengan lapang dada akan menerima semua perbedaan pendapat dan keyakinan, sebab dengan cara demikian seorang muslim dapat dikatakan menghayati pesan agama bahwa perbedaan adalah rahmah. Spirit profetik ini menjadi inspirasi bagi teologi

${ }^{46}$ Fethullah Gulen, Toward Global...,hlm. 46

47Fethullah Gulen, Toward Global..., hlm. 48 sosial yang harus dikembangkan dalam konteks kontemporer.

Jika dicermati, pandangan Gulen sangat dipengaruhi oleh konsep agama cinta Ibnu Arabi. Menurut Ibnu Arabi, agama cinta merupakan esensi dari seluruh kredo, oleh karena itu Ibnu Arabi menerima semua bentuk keyakinan dan persepsi ummat beragama tentang apa yang diasumsikanya sebagai pencipta. ${ }^{48}$ Namun Gulen agak berbeda, ia tidak berbicara lebih jauh tentang trancendental unity of religion, ia lebih menakankan cinta dalam proses dialog dan interasksi sosial antar ummat beragama.

Gulen mempromosikan bahwa cinta, toleransi dan kasih sayang adalah nilai-nilai Islam yang paling fundamental. Ia mengkritik kecenderungan bertauhid secara "liar" dan agresif yang diusung oleh beberapa kalangan. Model beragama yang radikal akhirnya kan mencederai Islam itu sendiri. Padahal, Islam secara harfiah bermakna "damai", namun kelompok tertentu menodainya dengan tindakan teror. Menurut Gulen, Muslim sejati tidak mungkin menjadi seorang teroris. ${ }^{49}$ Kesalahan terbesar yang menimbulkan tindakan teror adalah mis-interpretasi konsep jihad. Jihad menurut Gulen, merupakan elemen penting dalam Islam yang mengacu pada "inner struggle of believer against all that stand between the believers and God". 50 Bukan pada tindakan menyerang orang lain, yang didorong oleh kebencian.

Jadi, pandangan tauhid Gulen menggunakan paradigma teologis-etik,

${ }^{48}$ Media Zainul Bahri, Satu Tuhan Banyak Agama : Pandangan sufistik Ibnu Arabi, Rumi dan aljili (Jakarta : Mizan Publika, 2011) hlm.17-18

49"Just as Islam is not religion of terorisme, any muslims who correctly understands Islam cannot be or become terorist" lihat Fehullah Gulen, Toward Global.., hlm. 181

${ }^{50}$ Fethullah Gulen, Toward Global...,hlm.180 
degan mengedepankan cinta dan humanisme. Kesadaran akan kehendak tuhan atas keragaman ciptaanya, menjadi basis epistemologi pandangan tauhid fethullah Gulen. Konteks global dan negara bangsa, harus menumbuhkan kesadaran objektifikasi bahwa ummat Islam adalah bagian dari ummat-ummat lainya di bawah payung negara dengan sistem demokrasi, dan harus hidup secara bersama-sama dalam suana damai. Ummat Islam juga harus terlibat dalam gerak sejarah peradaban manusia, dengan memberikan kontribusi untuk menciptakan dan menjaga harmoni di muka bumi ini. Maka dengan demikian, Islam akan benar-benar menjadi Rahmatan lil alamin.

\section{b. Al-Qur'an, Nabi Muhammad Dan Sense of Multiculturalisme}

Sebagai seorang teolog, Pemikiran Fethullah Gulen tentunya tak bisa dilepaskan dari sumber otoritatif dalam Islam yaitu al-Qur'an dan Living tradition di masa Nabi (baca : sunnah) baik periode Makah maupun Madinah. Konsepsis teologisnya dibangun atas dasar dua sumber tersebut. Ia mengambil beberapa spirit dari ayat-ayat al-Qur'an dan etika moral rasul yang dipraktikanya dalam kehidupan.

Tuhan menciptakan tiap-tiap ummat serta mengirimkan bagi mereka pemimpin (likulli ummatin rusu>l). Pemimpin tersebut dalam tradisi agama-agama samawi disebut nabi. Nabi dikirim ke dalam sebuah komunitas untuk menyampaikan pesan (wahyu) sebagai way of life. Tugas kenabian adalah untuk mengajar ummat tentang hakikat penciptaanya, eksistensinya sebagai hamba dan kewajibanya untuk mentaati perintah sang pencipta.

Selain tugas di atas, Nabi memiliki tugas dalam kehidupan sosial yang tak kalah penting, yaitu membagun relasi sosial dan sistem kehidupan yang harmonis. Dalam ajaran Islam, Nabi Muhammad adalah tauladan (Uswah Hasanah), maka dari itu, ummat Islam harus belajar dari napak tilas dan mencontohi etika-moral beliau. Ada begitu banyak "hikmah" yang bisa dipetik dari keluhuran budi Rasulullah untuk dijadikan pelajaran dalam menghadapi kehidupan multikultural.

al-Qur'an dan Hadis banyak berbicara tentang multikulturalisme, utamanya tentang kebebasan beragama, kesetaraan manusia dan kehendak tuhan menciptakan keragaman atas mahluk. Meskipun demikian, ada pula teks yang yang ditafsirkan kemudian digunakan oleh sebagian kalangan untuk menyangkal hal tersebut, utamanya dalam konteks kebebasan beragama. Salah satu contoh misalnya ayat al-Qur'an terkait dengan persoalan "jizyah"; beban pembayaran bagi non-Muslim "perangilah orang-orang yang tidak beriman kepada Allah dan tidak pula kepada hari akhir dan mereka tidak mengharamkan apa yang telah diharamkan oleh Allah dan rasulnya dan tidak beragama dengan agama yang benar, yaitu orangorang yang telah diberikan al-Kitab kepada meraka, sampai mereka mebayar jizyah dengan patuh dan mereka dalam keadaan tunduk (QS.9:29) dan satu teks Hadis yang melaporkan bahwa Nabi menindak tegas dengan hukuman mati bagi orang yang murtad (baca : pindah agama). Matan hadis tersebut berbunyi "barangsiapa yang murtad; mengganti agamanya, maka bunuhlah dia "51

Dua sumber otoritatif di atas, sering digunakan secara luas oleh sebagian muslim untuk melakukan tindakantindakan intoleran dan ekstrimis. Penafsiran atas teks ini dalam konteks multikultural menjadi sangat problematik.

51Sahih Bukhari, 9, 84, hadith 57 
Menyikapi hal ini, Gulen menegaskan bahwa "Islam is religion of universal mercy" dengan mengutip Qur'an surat al-Rahman ayat 1-5 " Tuhan yang maha penyayang, dia telah mengajarkan al-Qur'an, dia menciptakan manusia, dan mengajarnya pandai berbicara (QS 55:1-5). ${ }^{52}$ Dalam ayat tersebut sangat jelas bahwa Allah menegaskan identitasnya sebagai "alRahman", kemudian dengan sifat rahman tersebut Allah menurunkan al-Qur'an sebagai "way of life". Dalam ayat selanjutnya Allah juga menyatakan bahwa Dia yang menciptakan manusia. manusia dalam ayat ini mencakup seluruh manusia dengan segala perbedaanya, baik dari segi agama, ras, bahasa dan tradisi. Kemudian Allah juga mengklaim diriNya lah yang mengajakan manusia pandai berbicara. Semua semua hal di atas dimulai dan diliputi oleh sifat "al-RahmanNya".

Prinsip dasar dari kebebasan beragama dalam pandangan dunia al-Qur'an berkait erat dengan visi al-Qur'an tentang "manusia sebagai sebagai mahluk". Dalam persfektif antroposentris, tuhan menciptakan manusia sebagai "ahsani taqwim" (QS 95 : 4), Allah juga menegaskan sikap pemuliaanya kepada "Bani Adam"; seluruh manusia tanpa terkecuali (QS 17:70). Kemudian al-Qur'an menekankan bahwa manusia secara inheren memiliki martabat dan kemuliaan. Dari itu, Allah memberikan kepada manusia akal dan kemampuan untuk membedakan antara yang benar dan yang salah (QS 17 :15 dan 6: 104)

Kebebasan memilih juga telah secara tegas dinyatakan oleh al-Qur'an" sungguh telah datang kebenaran dari sisi Tuhanmu, maka barangsipa yang ingi beriman, hendaklah ia beriman dan barangsiapa yang ingin kafir hendaklah ia kafir...." (QS 18:29)

${ }^{52}$ Fethullah Gulen, Toward Global..., hlm. 63 dan juga " barangsiapa yang berbuat baik dengan hidayahNya maka sesunguhnya dia berbuat baik untuk keselamatn dirinya, dan brangsiapa yang sesat maka sesungguhnya dia tersesat bagi kerugiany sendiri" (QS 17:15). Dalam ayat lain juga dikatakan “ tidak ada paksan dalam agama” (QS 2: 256). Maka berdasarkan ayat-ayat tersebut, iman atau keyakinan adalah sebuah pilihan individu dan piliha itu merupakan urusan individu dengan Tuhan. Oleh karena itu, pemaksaan kehendak atas kelompok lain agar ememiliki keyakinan yang sama dengan kita tidak dapat diterima dan tidak dibenarkan. Bahkan dalam kasus ini, Nabi pun pernah diperingatkan di dalam alQur'an " maka berilah peringatan, karna sesungguhnya kamu hanayalah orang yang memberikan peringatan"(QS $88: 21)$.

Maka sangat jelas beberapa ayat di atas menegaskan manusia sebagai mahluk bebas memilih. Fethullah Gulen terinspirasi dari ayat-ayat di atas, sehingga ia lebih memilih jalan dialog daripada memaksakan kehendak dan mempengaruhi orang lain untuk memngikuti Islam. karena baginya pluralitas agama dan budaya adalah 'sunnatullah'. Jadi, hal yang paling urgen menurutnya adalah mencari jalan damai menuju harmoni di tengah berbagai perbedaan baik agama maupun budaya.

Selain terinspirasi dari al-Qur'an, pandangan-pandangan Gulen juga diinspirasi oleh rasululullah; Nabi Muhammad. Dalam konteks perbincangan ini, penulis akan fokus untuk melihat peran Nabi di Madinah dalam membangun sistem sosial dan pemerintahan yang adil, terbuka dan menciptakan harmony in diversity. Sebagai seorang teolog, Fethullah Gulen banyak mengambil Inspirasi dan spirit toleransi dan dialog yang dilakukan nabi dalam kontesk Madinah. Kehadiran Nabi di Madinah membawa perubahan signifikan bagi masyarkat Madinah yang telah 
mengalami konflik antar suku dan antar agama berlarut-larut. Nabi berhasilkan mendamaikan dan menyatukan semua kalangan yang terdiri dari berbagai suku, kabilah dan agama. Jika melihat struktur sosial masyarakat Madinah saat itu, maka boleh dikatakan madinah adalah negara Multikultural.

Di bawah kepemimpinan nabi, struktur masyarakat Madinah yang multikulturalistik, dapat diatur sebagai masyarakat yang harmonis. Hal tersebut dilakukan dengan cara menghapus berbagai sekat primordialisme baik yang berlatar belakang agama, suku, maupun satus sosial. di atas semua perbedaan yang ada, nabi menganjurkan semangat persatuan antar penduduk Madinah. Agar bangunan kesatuan masyarakat Madinah memiliki kekuatan hukum yang legal, maka nabi mempelopori lahirnya konstitusi Madinah; konstitusi yang menjadi kesepakatan dan tanggung jawab bersama masyarakat Madinah untuk melaksanakanya, demi persatuan. Konstitusi ini kemudian lebih dikenal dengan sebutan "Piagam Madinah".

Melalu Piagam Madinah, nabi mengendalikan sistem pemerintahan, baik yang terkait dengan urusan internal Madinah, maupun urusan di luar Madinah. Prinsip dasar pemerintahan Madinah adalah unity in diversity. sebagai langkah awal, nabi berusaha mempersaudarakan sahabat yang dari makkah (Muhajirun) atau sebut saja non-pribumi dengan sahabat Madinah (anshar); penduduk pribumi. Persaudaraan dua kelompok ini sangat kokoh, sehingga mampu mengahalau provokasi-provokasi yang muncul dari kalangan Yahudi dan Nasrani Madinah. Hingga akhirnya kaum Yahudi dan Nasrani bersepakat untuk masuk dalam lingkaran kesepakatan Piagam Madinah.

Menurut Muhammad Shoelhi, ada beberapa poin yang termuat di dalam
Piagam Madinah, antara lain; pertama, Pentingnya kesatuan dan ikatan nasionalisme dalam bingkai negara, demi tercapainya cita-cita berasama, hal ini termuat dalam pasal 17, 23 dan 42. Kedua, pentingnya persaudaraan diantara ummat beragama baik antar sesama muslim mapun non-muslim, hal ini tertuang pada pasal 14, 15, 19 dan 21. Ketiga, Negara mengakui dan melindungi kebebasan beragama dan menjalankan ibadah sesuai dengan agama masing-masing, soal ini dijelaskan pada pasal 25, 26, 27, 28, 29 dan 30. Keempat, tradisi masa lalu atau kearifan lokal yang tetap berpedoman pada prinsip keadilan dan kebenaran tetap dipertahankan dan diberlakukan sebagaimana adanya, penjelasan terkait soal ini di pasal 2 dan 10 . Kelima, seluruh warga negara memilik hak dan kewajiban yang sama dalam menjalankan tugas negara, dijelaskan dalam pasal 18,24,36,37,38 dan 44. Keenam, setiap warga negara memiliki kedudukan yang sama di muka hukum, pasal 34, 40 dan 46. Ketujuh, semua warga negara, wajib saling membantu dan tidak diperkenankan berbuat zalim, adapun orang yang lemah harus dilindungi. Kedelapan, hukum harus ditegakan tanpa kecuali, siapapun pelanggar hukum tidak boleh dilindungi, demi tegaknya kebenaran dan keadilan, tertera pada pasal 13, 22 dan 43. Kesembilan, kedamian merupakan tujuan utama, namun untuk mencapai kedamaian tidak boleh mengorbankan keadilan dan kebenaran, pasal 24. Kesepuluh, menghormati hak setiap orang, tertuang di pasal 12. Kesebelas, pengakuan atas hak pilih individu. 53

Poin-poin di atas menunjukan betapa Nabi Muhammad sangat bijak dan sangat laik disebut sebagai agen pro-

${ }^{53}$ Mohammad Shoelhi (ed), Demokrasi Madinah: Model Demokrasi cara Rasulullah,( Jakarta :Republika,2003) hlm21-22 
multikulturalisme. Kebijakan-kebijakan yang tertuang di dalam piagam Madinah tentunya merupakan hasil dari strategi dialog dan toleransi yang diterapkan nabi dalam berinteraksi dengan komunitas Madinah. Fethullah Gulen dalam beberapa tulisanya, selalu memuji keluhuran budi pekerti rasul, terutama dalam konteks madinah. hal tersebut menjadi inspirasi besar baginya dalam menghadapi 'global civilization'. Dengan mentauladani rasul, Gulen menekankan dua hal tersebut; dialog dan toleransi, yang harus dikembangkan dalam mengahadapi global civilization dan multikulturalisme. Dialog menurut Gulen merupakan sesuatu yang mengajak kepada pencarian titik temu, hal ini sebagaimana diungkapkannya :

Another aspect of establishing and maintaining dialogue is the neccessity of increasing the interests we have in comon with other people. In fact, even if the people we talk with the Jews and cristians, this aproach still should be adopted and issues that can be separate us should be avoided altogether. ${ }^{54}$

Dari ungkapan tersebut, sangat jelas bahwa upaya dialog bagi Fethullah Gulen ialah momen pencarian titik temu (kalimatun sawa') dan kesamaan kepentingan dengan orang lain. Bahkan ketika harus berdialog dengan kelompok Yahudi maupun Nasrani, pendekatan dialog harus tetap berorientasi pada pencarian kesamaan atau titik temu yang dimiliki bersama. Adapaun terkait isu-isu yang bisa memecah belah baik antara Islam, Yahudi dan Nasrani harus dijauhi secara bersamasama.

Toleransi merupakan salah satu sifat rasul. Rasul dididik menjadi toleransi oleh

${ }^{54}$ Fethullah Gulen, Toward Global..., hlm.72
Allah sendiri. Dalam satu riwayat, Nabi menyatakan "aku diutus menjadi fleksibel dan toleran"55 Meskipun "toleransi" tidak ada secara spesifik dalam Asma' al-husna, namun, akar dari toleransi terdapat dalam sifat-sifatNya seperti; Maha pengampun, Maha pemaaf, Maha penyayang bagi semua mahluk. ${ }^{56}$ Toleransi merupakan elemen yang paling esensial dalam sebuah sistem moral. Ia merupakan sumber paling penting dari disiplin spritual dan kebajikan. terkadang toleransi digunakan semakna dengan respek, penuh maaf, kemurahan dan ampunan. terkait dengan bagaimana seharusnya kita bersikap toleransi, Gulen menyatakan ;

We should have such a tolerance tha we are able to close our eyes to the faults of other, to have respect for different ideas, and to forgive everything that is forgivable. In fact, even when we faced with violations of our inalienable rights, we should remain resfectfull to human values and try to establish justice. ${ }^{57}$

Kita harus memiliki sikap toleransi, karena dengan sikap tersebut kita tetap bisa bersikap wajar atas kesalahan orang lain, menghormati perbedaan pendapat, dan memaafkan segala sesuatu yang bisa dimaafkan. Meskipun bahkan ketika kita dihadapkan pada kekerasan atas hak-hak kita. kita harus tetap respek pada nilai-nilia kemanusiaan dan menegakan keadilan.

Jika membaca kembali lembaranlembaran sirah nabawiyah, terutama dalam kontesk Makkah. kita akan menjumpai cerita-cerita kekejaman kaum Quraisy terhadap rasul. Hinaan, cercaan, caci-maki secara bertubi-tubi diterima beliau, namun

\footnotetext{
55. الحنبفية

56Fethullah Gulen, Toward Global..,hlm. 70

57Fethullah Gulen, Toward Global...,hlm.73
} 
beliau tetap sabar dan memaafkan semua itu. Rasul memahami apa yang mereka lakukan telah melewati batas, namun rasul tidak ingin membalas sedikitpun, karena nabi memandang mereka sebagai manusia. sejelak-jelak manusia, selama manusia itu masih menjadi manusia, pasti pada waktu tertentu sifat-sifat kemanusiaan sebagai fitrahnya akan muncul lagi. Maka kata "maaf dan toleransi" bagi nabi, tak boleh hilang dari kehidupan manusia.

Kesadaran multikultural yang ditunjukan rasul di Madinah, dijadikan Inspirasi oleh Fethullah Gulen dalam melakukan kegiatan-kegiatan dialog interfaith dan intercultural. Selain itu, pandanganya tentang multikulturalisme didasarkan pada ajaran-ajaran al-Qur'an. Fethullah Gulen, merujuk surat al-hujurat ayat 13 sebagai dasar sense of multiculturalism :

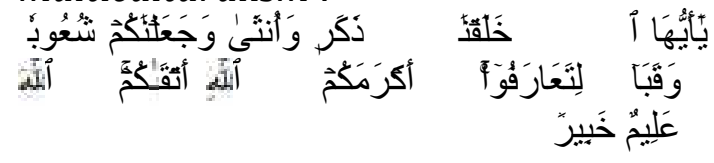

"Wahai manusia, sesungguhnya kami telah menciptakanmu dari lakilaki dan perempuan, dan kami jadikan kamu sekalian bersuku-suku dan berbangsa-bangsa agar kalian saling kenal-mengenal, sesungguhnya orang yang paling mulia di sisi Allah adalah orang yang paling bertaqwa diantara kamu. Sesungguhnya Allah maha mengetahui"

berdasarkan ayat di atas, kehadiran beragam etnik, agama, suku, ra s adalah ketentuan tuhan. dalam ruang publik bukan alasan menjadi faktor konflik. Tetapi semestinya keragaman tersebut menjadi sarana untuk berdialog, bertukar pikiran dan gagasan untuk menciptakan "common good". Itulah bentuk ejawantah dari perintah "lita'a>rafu>" dalam ayat di atas. Oleh karena itu, peran aktor-aktor dalam ruang publik sangat dibutuhkan. Di sinilah para pemikir muslim sebagai aktor, harus memainkan peranya untuk saling berbagi dan berdialog guna menciptakan "living system" melalui kesadaran akan pentingnya "peacefull co-existence in multicuturalisme context".

\section{c. Islam dan Demokrasi}

Sejak awal, teologi Islam diwarnai oleh wacana politik. terutama pasca wafatnya rasul. Pertarungan wacana antar sekte kalam berkutat pada persoalan politik. Namun dalam konteks modern, isu khilafah dan imamah sepertinya tidak relevan lagi untuk diperdebatkan. karena wilayahwilayah Islam sudah terpecah menjadi negara bangsa. ummat Islam harus hidup secara bersama-sama dengan komunitas lain yang berbeda secara agama, ras dan budaya di bawah sistem demokrasi. Maka yang layak dikaji dan didisikusikan lebih jauh adalah konsep negara (state) dan kewarganegaraan (citizenship). Meskipun demikian, sepertinya wacana klasik tentang Imamah dan khilafah masih mewarnai perdebatan konsep negara Islam. Hal ini bisa dilihat dengan kemunculan kelompokkelompok yang mengusung ide khilafah sebagai sistem negara.

Kemunculan "Islamic group" yang paling fenomenal akhir-akhir ini misalnya ISIS -untuk menyebut salah satunya- dan masih banyak lagi kelompok lainya yang memiliki ide-ide Islamisasi politik. sebagian sarjana barat semisal Bernad Lewis (2002), Ellie Kedurie (1994) dan Albert Hourani (1961) ${ }^{58}$, menilai kelompok-kelompok tersebut sebagai gerakan non-civil society. Namun belakangan, penilaian terhadap kelompok-kelompok Islam itu, memberikan

${ }^{58}$ Lihat, Paul Weller and Ihsan Yilmaz, European Muslim, Civility and Public life, hlm. 57 
semacam generalisir terhadap Islam. kelompok-kelompok tersebut dianggap sebagai reprenstasi Islam secara umum. Menurut penulis, Di sinilah letak bias pandangan barat terhadap Islam. Pandangan tersebut terjebak pada hasilhasil riset tentang Islam yang difokuskan pada kelompok "Islamist" dan kemudian dikonstruk menjadi pandangan umum atas Islam.

Generalisasi "Barat" atas "Islam" berimplikasi pada pembentukan citra negatif atas Islam sebagai agama teror. Jika diperhatikan secara seksama dan jujur, mayoritas muslim tidak terlibat dalam gerakan-gerakan radikal memiliki tendensi politik. meskipun harus jujur diakui, memang ada sebagian kelompok yang melakukan hal itu. sebagian besar risetriset yang dilakukan sarajana barat, cenderung megeneralisir Islam sebagi agama teroris, kesimpulan ini boleh jadi dipengaruhi oleh bias orientalis dalam mengkonstruski timur, terutama Islam. 59

Kelompok tertentu dari kalangan muslim (baca: Islamist) yang menunjukan sikap anti barat dan demokrasi secara berlebihan, bahkan sampai melakukan tindakan-tindakan agresif, cenderung menjadikan Islam sebagai instrumen politik untuk melawan dominasi dunia barat.60 Padahal Islam sesunguhnya adalah sebuh visi moral bagi gerakan kemanusiaan. Di tengah menguatnya pandangan negatif terhadap Islam. ada satu pendapat yang agak berbeda dari salah seorang sarjana barat yaitu Clarck. ia mengatakan, terdapat beberapa analisis yang berbahaya dalam

${ }^{59}$ Lihat Wanda Krause, Civility in Islamic Activisme:Toward a Better Understanding of Shared Values for Civil Society development, dalam Paul Weller and Ihsan Yilmaz (Ed), European Muslim, Civility and Public, hlm. 58

${ }^{60}$ Mustafa Akyol, Islam Without Extremes, A Muslim Case for Liberty (New York, NY: Norton House Inc, 2011), hlm. 198. menilai Islam, hal ini disebakan karena banyak peneliti gagal membedakan antara "minority of violent Islamist group" dan "majority of non violent islamist group". Kegagalan membedakan dua hal tersebut, menyebabkan Islam selalu digeneralisir sebagai sebuah kumpulan orang yang anti demokrasi dan kelompok barbar(baca : radikal). ${ }^{61}$

Dalam Hingar-bingar dan riuhnya isu Negara Islam dan Khilafah yang diusung kelompok Muslim tertentu biasa diesebut "Islamis". Gulen justru berpendapat demokrasi adalalah sistem pemerintahan yang tepat dan masuk akal di zaman ini. Ia menolak Islam politik, yang hanya menjadikan agama sebagai ideologi politik. $^{62}$ Ia juga mengkritik kelompok Islamis yang dianggap berperan dalam pembentukan citra buruk Islam dalam pandangan barat, ia mengatakan :

Muslims cannot act out of ideological or political partisanship and then dress this partisanship in Islamic garb, or represent mere desires in the form of ideas; strangely enough, many groups that have put themselves forward under the banner of Islam export a distorted image of Islam and actually strengthen it. 63

Fethullah Gulen sadar bahwa negara bangsa sudah memisahkan ummat Islam secara teritorial. sehingga ummat Muslim sudah menjadi identitas "warga negara" dalam sebuah negara dan memiliki hak dan tanggung jawab. Ia menekankan pada fleksibelitas prinsip-prinsip Islam dalam

${ }^{61}$ Wanda Krause, Civility..., hlm 58
${ }^{62}$ Fethullah Gulen, Toward Global...,hlm. 58
${ }^{63}$ Fethullah Gülen's comments in Turkish Daily News National, January 11, 2000 dalam Uğur Kömeçoğlu, Islamism, Post Islamism and Civil Islam..hlm. 25 
urusan pemerintahan dan mendialogkanya dengan proses demokrasi. Terlepas dari berbagai sisi negatifnya, demokrasi bagi Gulen merupakan satu-satunya sistem politik alternatif di dunia modern. 64

Gulen memandang demokrasi sebagai sebuah sistem yang memberikan kesempatan bagi setiap orang yang hidup dibawah naunganya, kebebasan untuk hidup dan mengekspresikan perasaan dan pendapatnya. Oleh karena itu ia menekankan urgenya sikap toleransi. karna dalam negara yang menggunakan sistem demokrasi, sikap toleran adalah harga mati. Demokrasi taka akan akan eksis jika tak didukung oleh sikap toleransi warga negaranya. ${ }^{65}$

Islam dan demokrasi seringkali dibandingkan, bahkan di perhadaphadapkan (binary opposition). Sebagian kelompok yang memperhadapkan Islam dan demokrasi, bertujuan untuk memperlihatkan sisi keunggulan Islam atas demokrasi. melalaui klaim keuunggulan Islam atas demokarasi, kemudian dijadikan justifikasi agenda-agenda Islamisasi sistem pemerintahan dan politik (Khilafah). Menurut penulis, Penting untuk dicatat, bahwa sebelum membandingkan Islam dan demokrasi, maka terlebih dahulu kita harus fokus pada aspek kehidupan sosial (social life). Islam sebagai "keyakinan" tidak bisa dibandingkan pada basik yang sama dengan demokrasi sebagai sistem politik, Karena agama lebih fokus pada aspek permanen (tsawabit) dalam hidup manusia sebagai pemeluk agama. Sedangkan sistem demokrasi konsen pada variable aspek kehidupan sosial manusia yang berubah dan bersifat duniawi. ${ }^{66}$ Maka, aspek-aspek yang harus dibandingkan antara Islam dan

${ }^{64}$ Fethullah Gulen, Essay, Persfektives, and Opinion (New jersey, Thugra Books, 2009) hlm. 4 ${ }^{65}$ Fethullah Gulen, Toward Global..., hlm. 44 66Fethullah Gulen, Toward Global...,hlm.221 demokrasi adalah pada aspek-aspek antroposentris (Baca: Mu'amalah). Bahkan rasul pun mengaskan itu dalam sebuah hadis "antum a'almu bi umu>ri duniyakum". Terkait hubungan antara Islam dan demokrasi Gulen Menyatakan:

When comparing religion or Islam
with democracy, we must
remember that democracy is a
system that is being continually
develop and revised. It also varies
according to the place and
circumtances where it is practiced.
On the other hand, religion has
established immutable principles
related to faith, worship and
morality, thus, only Islam's wordly
aspect should be compared with
democracy. ${ }^{67}$

Berdasarkan statemen di atas, Gulen mengakui bahwa demokrasi bukanlah sesuatu yang baku, demokrasi senantiasa terus dikembangkan dan diperbaiki. sedangkan sebagian kelompok yang anti demokrasi, telah melakukan perbandingkan antara Islam dan demokrasi secara keliru. Mereka membandingkan Islam sebagai keyakinan, maka jelaslah akan selalu ada tendensi. menurut Gulen, Islam memiliki aspek yang qat'i seperti ibadah mahdlah dan di sisi lain Islam juga memiliki dimensi Ijtihadi, seperti persolan-persolan sosial kemasyarakatan. Dalam hal ini, sistem pemerintahan termasuk dalam aspek sosial yang berada pada wilayah ijtihadi. Maka, perbandingan yang tepat adalah membandingkan demokrasi dengan aspekaspek sosial-etik Islam pada wilayah ijtihadi (mutahawwil); yang selalu berubah sesuai kebutuhan ummat dan narasi sejarah.

Menurut penulis, Pandangan Gulen mengenai persinggungan Islam dan

67Fethullah Gulen, toward Global...,hlm.221 
demokrasi, memiliki rasionalisasi idealreligius dengan menampilkan nilai-nilai etik universal Islam yang sesuai dengan konteks modern sekuler. Mengingat ia adalah seorang sufi master, hal ini tentunya merupakan proyeksi pandangan dunia mistisme kepada pemahaman tentang sekularisme. Sekularisme di sini, dalam persfektif Gulen sangat terkait dengan usahanya untuk mengcounter binari oposisi yang dibentuk oleh Islamis antara Islam dan pluralisme modern dalam ruang demokrasi. Ia berusaha menghindari dikhotomi kaku antara Islam dan non-Islam, Dar-al Harb (place of war) dan Dar-al Islam (place of Peace), sebagaimana dicitakan para kelompok Islamist. Distungsi semacam itu tidak perlu, kerena distingsi tersebut seringkali melahikan konflik horizontal yang destruktif. Dalam kontekas modern dan demokrasi, Gulen menawarkan Dar-al Hizmet (place of service), sebuah dunia pengabdian untuk sesama dan kemanusiaaan. 68

Sebagian muslim memandang modernisasi dengan segala pirantinya termasuk demokrasi- adalah produk barat dan tidak layak ditiru. Islam dan Modernisasi seolah-olah dijadikan dua kutub yang saling bertentangan. Terkait hal itu, Gulen berusaha mengikis elemenelemen yang menumbuhkan potensi konflik antar kepentingan religius dan dunia modern. Menurutnya, Kegagalan kalangan Muslim dalam proses modernisasi, disebabkan ketidakmampuan mensinergikan antara agama, sains dan revitalisasi pendidikan. ia menegasakan bahwa sain dan agama tidaklah berlawanan. Menurutnya, dengan memanfaatkan sain modern, kaum muslim akan semakin memahami keteraturan alam semesta. dari pengetahuan tersebut semestinya kaum

68 Lihat, Uğur Kömeçoğlu, Islamism, Post Islamism and Civil Islam muslim akan semakin memahami kemahakuasaan Tuhan. Dari proses sinergi agama dan Sain akan terkait aspek esoterik dan pemahaman spritual Islam. Gulen pun menegaskan pandanganya tentang sekularisme modern,

Secularization is an inevitable characteristic of human nature. But man is not only a body. He has a soul, too. He has a metaphysic dimension besides the physical one. He has both sacred and profane aspects. Therefore a perfect democracy can welcome both the physical and metaphysical needs of its subjects. 69

Pemahaman Gulen tentang sekularisme terkait dengan usahanya untuk mengkonter binari oposisi yang dibentuk oleh Islamis antara Islam dan pluralisme modern. Gulen tidak menciptakan perbedaan yang kaku seperti yang diciptakan Islamis antara Islam dan non-Islam, dar-al Harb (place of war) and Dar-al Islam (place of Peace), kerena distingsi tersebut seringkali melahikan konflik horizontal yang destruktif. Gulen menegaskan bahwa bahwa dunia modern adalah Dar-al Hizmet (place of service). Tak perlu lagi ada distingsi semacam itu.

Berdasarkan persfektif sekuler yang dibentuk Gulen dan ide pengabdian kepada kemanusiaan, maka sangat jelas bahwa gulen menggunakan pedekatan civil Islam. bahkan, ia tidak menempatkan ummah sebagai entitas politik, tetapi ia menempatkanya dalam ruang sosial budaya, yang secara internal beragam, dan tidak mengambil sikap opoisisi terhadap dunia non-Muslim. Maka dari itu, pemikiran Fethullah Gulen, meginisiasikan dan menganjurkan untuk terus melakukan

${ }^{69}$ Fethullah Gülen's comments in Samanyolu Television channel (STV - Haber Kritik), March 29, 1997. 
kegiatan dialog interfaith dan intercultural, untuk mengurangi "clash" antara Islam dan Barat. Sebagaimana diungkapakan oleh John O. Voll ;

"in the clashing visions of globalizations, F. Gulen is a force in the development of the Islamic discourse of globalized multicultural pluralism. As the impact of the educational activities of those influenced by him attests, his vision bridges modern and postmodern, global and local, and has a significant influence in the contemporary debates that shape the visions of the future of Muslims and nonMuslims alike."70

Berdasarkan statemen di atas, maka posisi Fethullah Gulen sangat jelas dalam proses pengembangan wacana keIslaman dalam konteks globalisasi multikulturalpluralisme. Sebagai dampak dari pendidikan yang dipengaruhil oleh pemikirannya yang mencerahkan, dia menjembatani modern dan posmodern, global dan lokal, dan ia memiliki pengaruh besar dalam diskusi-diskusi kontemporer mengenai visi tentang masa depan Muslim dan non-Muslim untuk hidup secara bersama-sama.

\section{d. Aktivisme Sosial: Hizmet, Pendidikan dan Multikulturalisme}

Hizmet movement adalah gerakan berpusat di Turkey; aktif dalam dunia pendidikan, civil society, bisnis dan

${ }^{70}$ John O. Voll, "Fethullah Gulen Transcending Modernity in the New Islamic Discourse," dalam Yavuz, M. Hakan and Esposito, John L. Turkish Islam and the Secular State (Syracuse, NY: Syracuse University Press, 2003), hlm. 247. kegiatan-kegiatan lain di sekitar 150 negara di dunia. Gerakan ini didasarkan pada pemikiran-pemikran Gulen, yang menekankan nilai-nilai spritual dan humanisme dari tradisi Islam. Gerakan ini merupakan sebuah gerakan kultural; nonpolitik dan gerakan edukasi yang memiliki prinsip dasar nilai-nilai universal Islam, seperti cinta pada seluruh makhluk tuhan, simpati pada kemanusiaan, dan menjunjung sikap altruisme ( $i>t$ tsar). ${ }^{71}$

Hizmet merupakan kosakata bahasa turki yang berasal dari akar kata bahasa Arab "Khidmah"; yang berarti pelayanan (serving). Pemikiran tentang hizmet memilik pendasaran dari ajaran Islam dan berkait erat dengan kesalehan. bagi Gulen, kesalehan harus ditunjukan dengan aksi nyata. Pun demikian halnya Iman adalah applied action, yang tak cukup pada level keyakinan semata. Dengan pelayanan yang tersebar di berbagai belahan dunia, Gulen movement menjadi gerakan civil terbesar. ${ }^{72}$

Salah satu tujuan utama Hizmet adalah untuk menumbuhkan kesadaran komunitas muslim agar dapat menyessuaikan diri dengan corak masyarakat demokratis. Dan Hizmet juga sebagai kritik terhadap Islamist. Bagi Gulen, gerakan-gerakan kelompok Islamis biasanya dimotivasi oleh kepentingan kelompok dan agenda politik yang didasari ambisi keduniawian dan kekuasaan, dengan bersikap radikal dan cenderung melakukan kekerasan. Sebagai gerakan Islam, Hizmet mencoba untuk merevitalisasi iman. dan percaya bahwa Islam memiliki aturan untuk memainkan peran dalam proses pemberdayaan dan penguatan civil dan kehidupan politik yang demokratis. Perbedaan yang cukup kontras

${ }^{71}$ Lihat, Fethullah Gulen Biografical Album, (Gulen Institute: e-paper) hlm. 21-23

${ }^{72}$ Lihat, Yavuz and Esposito, Turkish Islam and Secular State; The gulen Movement, (Syracuse :University press) hlm. xiii 
antara kelompok Islamis dan gerakan Hizmet adalah angota Hizmet tidak bertujuan mencari kekuasaan politik dan tidak pula untuk menyebarkan ideologi partai politik tertentu. Gerakan ini hanya bertujuan untuk mengimprovisasi masyarakat modern dan mengembangkan dan memajukan manusia dengan cara memperkuat spritualitas dan kesalehan individu. Karakter kesalehan yang dibentuk oleh ideologi gerakan Hizmet, konsen pada pembentukan karakter individu-individu, karena hal itu dipandang sangat penting. Gulen mengkritik keras kelompokkelompok yang menjadikan al-Qur'an sebagai Legitimasi untuk merebut kekuasaan politik,

The Quran is an explanation of the reflections of the divine names on earth and in the heavens... It is an inexhaustible source of wisdom. Such a book should not be reduced to the level of political discourse, nor should it be considered a book about political theories or forms of state. To consider the Quran as an instrument of political discourse is a great disrespect for the Holy Book and is an obstacle that prevents people from benefiting from this deep source of divine grace. ${ }^{73}$

Menurut Gulen, Qur'an sebagai penjelasan atas refleksi sifat-sifat dan asma tuhan baik di langit dan di bumi.. adalah sumber dari segala kebijkasanaan. Sebagai kitab suci al-Qur'an tidak boleh direduksi kepada wilayah wacana politik, tidak pantas juga dijadikan sebagai buku tentang teoriteori politik atau negara. Menjadikan alQur'an sebagai intrumen wacaa politik

${ }^{73}$ Fethullah Gülen, "An Interview with Fethullah Gülen," The Muslim World (Special Issue on Islam in Contemporary Turkey: The Contribution of Fethullah Gülen) Vol. 95, No. 3 (2005),hlm. 451. merupakan penghinaaan besar atas alQur'an sebagi kitab suci dan hal itu merupakan pengahlang terbesar bagi manusia untuk mendapatkan rahmat Tuhan.

Pemahman Gulen tentang Islam dan teks-teks Islam lebih menekanakankan pada aspek esoteris daripada eksoteris. Ketika para Islamis cenderung mempromosikan pemahaman yang lebih bersifat fiqhi dan politisasi tafsir atas alQur'an, pendekatan Gulen terhadap alQur'an bertujuan untuk menunjukan ajaran terdalamnya (deepest)) tentang spritualitas dan kerinduan manusia atas eksistensi tuhan. Terkait hal itu, Sesungguhnya, urgensi hukum syari'ah hanya disebutkan sebanyak dua kali di dalam al-Qur'an (42:13 and 45:18) sedangkan exigency iman termanifest dalam beberapa halaman. Melalui penafsiran yg rich dan literal, gulen membantu untuk menunjukan inner dinamika sprituality dari ajaran Islam. dan ia menekankan aspek pengalaman "selftrancendent" yang mungkin bagi semua orang dalam kehiduapn sehari-hari. Mengelaborasi beberapa aspect Islam tersebut Gulen secara khusus menulis buku Emerald Hills of Heart : Key concepts in Practice of sufism.

Sebagai aplikasi konsep hizmet dalam bentuk aktivisme sosial, para pengikut Gulen mengagas beberapa organisasi sosial untuk membantu mensejahterakan masyarakat, baik di dalam maupun di luar Turki. Organisasi sosial serta lembaga pendidikan yang dibentuk Fethullah Gulen, disponsori oleh para dermawan dari kalangan pengusaha yang terinspirasi dari ajaran-ajaran Gulen dan disupport pula oleh guru-guru yang tulus, serta para orang tua yang memiliki semangat untuk meyekolahkan anaknya. Sekolah-sekolah Gulen, antara lain tersebar di Turki bagian 
Tenggara, Asia tengah, Asia Timur dan Tenggara, Eropa dan juga Amerika.

Gerakan ini merupakan gerakan nonpemerintahan, tapi semacam gerakan civil society yang mendukung isu-isu demokrasi, keterbukaan terhadap globalisasi, progresivitas dalam mengintegrasikan tradisi dan modernitas. Fakta ini menjadi "counter narasi" terhadap pendapat para sarjana barat yang menilai nyaris semua "kelompok-kelompok Muslim" adalah gerakan radikal dan politis. Fenomena Gulen Movement mementahkan analisis para sarajana tersebut, karena Gulen Movement sebagai Islamic group tidak radikal dan non-politik. Bahkan gerakan ini justru memberikan kontribusi besar pada isu-isu kemanusiaan dan multikulturalisme di dunia. ${ }^{74}$

Pendidikan bagi Gulen, memiliki peran yang sangat penting. Karena hanya melalui pendidikan mindset masyarakat bisa dirubah. Kondisi sosial turki saat itu, telah mengilhaminya untuk menyebarkan ideidenya melalui jalur pendidikan. Karena hal itu merupakan langkah strategis untuk membangun kembali semangat para generasi muda turki yang telah kehilangan harapan. Selain itu, pendidikan juga seabgai simbol dari harmonisasi hubungan antar budaya dan kepercayaan, penyatuan iman dan nalar, serta dedikasi yang tulus pada sesama.

Bagi Gulen, humanity tidak akan pernah lahir ke dunia ini tanpa proses pendidikan. Pendidikan akan menghadirkan generasi muda yang memahami kepentingan dirinya sendiri dan orang lain. Sebagaimana ungkapan Gulen "I encouraged people to serve the country in particular, and humanity in general, trough education"75. Pandangan Gulen tentang pendidikan juga
${ }^{74}$ Wanda Krause, Civility...,hlm. 58
${ }^{75}$ Fethullah Gulen, Essay, perspectives..., hlm. ditulis oleh Charles Nelson, ia merangkum pokok-pokok pemikiran Gulen sebagai berikut :

The end of Gulen's educational
vision is to raise a "Golden
Generation" a generation of ideal
universal individual, individual
who love truth, who integrate
sprituality and knowledge, who
work to benefit society (Gulen,
1998) a merging of universal
ethical values with science and
modern knowledge (Gulen, 2004)
that produce "genuinly
enlightened people (Gulen, 1996)
who motivated by love, take
action to serve others (Gulen,
$2000)^{76}$

Jadi, visi pendidikan Gulen adalah untuk menciptakan "generasi emas" yaitu generasi yang berkepribadian ideal dan universal, yakni individu yang mencintai kebenaran, yang mengintegrasikan spritualitas dan ilmu pengethuan, yang bekrja untuk memberi manfaat pada masyarakat. menggabungan nilai-nilai etika universal dengan sain untuk menciptakan orang-orang yang tercerahkan secara genuin, yang selalu dimotivasi oleh rasa "cinta" dan beraksi untuk melayani sesama.

Gerakan Gulen menghindari keterlenaan pada romantisme masa lalu, mengenang masa kejayaan Islam dalam mimpi-mimpi indah yang membuat terlena namun hampa. Gerakan ini lebih memilih melakukan penyegaran terhadap modernitas dengan nilai-nilai tradisional. Tujuan utama gerakan ini adalah mendidik

${ }^{76}$ Charles Nelson, Fethullah Gulen : $A$ vision of trancedent education, (Fethullah Gulen Oficial web : e-paper) hlm. 6, diakses di web resmi Fethullah Gulen 1 juli 2015. 
generasi muda agar memiliki kedalaman spritual, kecerdasan intelektual dan berkomitmen untuk mengabdi untuk sesama. ${ }^{77}$ Hal tersebut sebagaimana statemen Gulen sebagai berikut :

It is an education of heart and souls as well as of the mind. Aimed at invigorating the whole being to achieve personal competence and the ability to be useful citizen for the benefit of others ${ }^{78}$

Dalam mengembangkan filosofi pendidikanya, Gulen berangkat dari pengalamanya melihat kelemahan pendidikan di turki. menurutnya ada dua hal penting yang menjadi problem pendidikan di Turki : pertama, lembaga pendidikan sekuler tidak bisa melepaskan diri dari "Prejudice" ideologi modern dan cenderung materialistis. kedua. Madrasa (traditional school) memiliki kelemahan dan kemunduran dalam bidang teknologi dan pengetahuan saintifik, Hal ini disebabkan oleh kurangnya semangat pengembangan ilmu pengetahun dan teknologi di dalam madrasa .

Menurut Gulen, pelajaran sains tidak harus dipisahkan dengan pengembangan spiritualitas. dalam pengembangan individu maupun sosial, harus adanya integrasi antara agama dan sains, spiritualitas dan intelektualitas, rasio dan wahyu, akal dan hati. Model pendidikan seperti inilah yang di kehendaki Gulen. Jadi, kesalehan dan spritulitas merupakan hal yang sangat urgen dalam pengembangan masyarakat, sebagaimana pernyataan Gulen :

Judge your worth in the creator's sight, by how much space he occupies in your

${ }^{77}$ Aslandogan, Present and potential impact of the spritual Tradition of Islam on contemporary muslim : From Ghazali to Gulen, hlm. 672

78Lihat, wanda Krause, Civility...,hlm. 59 heart, and your worth in people eyes by how you treat them. Do not neglect the truth even for a moment. And yet, "be human being among other human beings" 79

Kata kunci dari falsafah pendidikan Gulen adalah harmonisasi antara modernitas dan spiritulitas serta semangat pengabdian diri kepada sesama dengan penuh kesadaran multiculturalisme. Melihat agenda pendidikan yang gagas Gulen, sepintas agak mirip dengan konsep integrasi dan interkoneksi yang dikembangkan UIN Sunan Kalijaga Yogyakarta, sebagaimana digagas oleh Amin Abdullah. Gulen berpandangan bahwa sains dan iman tidak saja bersanding, tetapi juga saling melengkapi. Karena itu ia mendorong riset-riset ilmiah dan memanfaatkan kemajuan tekonologi untuk kebaikan ummat manusia. Dialog interfaith dan intercultural tidak cukup unutuk menciptakan harmoni, lebih dari itu, kita membutuhkan bahasa universal sebagai media pemersatu ummat manusia yaitu sains. ${ }^{80}$

Meskipun Gulen Movement identik dengan identitas muslim-Turki, namun gerakan ini berkembang ke berbagai belahan dunia, termasuk ke negara-negara berpenduduk mayoritas non-muslim. Uniknya, di negara-negara berpenduduk non-muslim, banyak komunitas non-muslim tertarik dan simpatik pada gerakan ini dan ikut menjadi volunter. Hal ini menunjukan bahwa prinsip-prinsip dasar dalam ajaran Gulen, mampu mempengaruhi orang-orang

${ }^{79}$ Wanda Krause, Civility...,hlm. 59

${ }^{80}$ Dalam dunia modern sains adalah milik semua orang dan berlaku universal, maka akan sangat efektif menjadikan sains sebagai bahasa bersama untuk mempertemukan manusia, disampaikan oleh Prof Amin Abdullah dalam kuliah filsafat Islam di Pascasarjana UIN Sunan Kalijaga Yogyakarta. 
yang berbeda baik secara agama, kultur dan budaya. Di titik inilah, kita bisa melihat kontribusi Gulen Movement sebagai gerakan yang menciptakan kesadaran multikultural.

\section{F. Simpluan}

Dari urain di atas, maka dapat disimpulkan beberap hal. Pertama, Modernisasi, pluralisme dan multikulturalisme adalah anomali bagi diskursus kalam klasik. Paradigma dogmatis-ekslusif kalam klasik mengalami kebuntuan ketika dihadapakan pada isu-isu seperti demokrasi, sekularisme, pluralisme, konsep negara dan kewarganegaraan. Sehingga dalam konteks ini, kalam klasik niscaya harus di-rethinking agar tetap memiliki kontribusi bagi kehidupan, dengan cara melakukan shifting paradigm ke arah teologi yang bersifat inklusive, dialogis dan progressif; yang penulis sebut dengan "teologi Sosial". Kedua, Pergeseran dari kalam menuju teologi sosial adalah sebuah upaya pembaruan dan reformulasi diskursus teologi Islam kedalam kontesk peradaban global, dengan tujuan revitalisasi fungsi teologi Islam dalam ruang publik, dengan menggali nilai-nilai tradisional Islam kemudian didialektikakan dengan nilai-nilai positif dalam peradaban modern. Ketiga, Pemikiran Fethullah Gulen, merupakan dinamika dari diskursus teologi kontemporer yang "aware" terhadap persoalan multiculturalisme. Pemikiranya memiliki aplikasi praksis untuk menjembatani "dialog antar peradaban", Dengan mengedepankan dua konsep kunci yakni "dialog dan toleransi", serta mengembangkan gagasan teologi cinta, Spirit multicultralisme dari al-Qur'an dan Etika-moral Nabi, dan Hizmet movement sebagai aplikasi praksis dari konspesi pandangan teologinya yang kosmopolit. Eksistensi pemikiran Ftehullah Gulen dan
Hizmet mivemenya, menjadi konter-narasi bagi analisis simplistis Huntington dengan tesisnya tentang "Clash of Cvilization" menuju "Dialogue Among Civilization"

\section{Daftar Pustaka}

Abdullah, Amin. Falsafah Kalam di Era Postmodernisme, Yogyakarta: Pustaka Pelajar,1995.

Abdullah, Amin. Islamic Studies di Perguruan Tinggi : Pendekatan integrative-interkonektif, Yogyakarta:Pustaka Pelajar. 2006.

Ahmad Baso, Posmodernisme sebagai kritik Islam :Kontribusi metodologi 'Kritik Nalar"' Muhammad Abed al-Jabiri, Yogyakarta : LKIs, 2000.

al-Ghazali, al-Munqidz min al-dala>l, Daralkitab al-Arabi t.t

Al-Ghazali, Iljam al-'Awwam an Ilmi alKala $>m$, Beirut : Dar al-Kitab al-Arabi. t.t.

Araby, Ibnu. al-Futu>ha>t al-Makkiyah, Mahmu>d Matraji> (ed), 8 volume, beirut : Da>r al-Fikr, 2002.

Arkoun, Mohammad. al-Isla $>m$ : al-Akhla $>q$ wa al-siya $>$ sah, terj Hasyim Salih, Beirut :1986.

Bahri, Media Zainul Bahri. Satu Tuhan Banyak Agama : Pandangan sufistik Ibnu Arabi, Rumi dan al-jili, Jakarta : Mizan Publika, 2011.

Bakara, Osman. Hierarki Ilmu, Bandung : Mizan, 1997. 
Charles Nelson. Charles Fethullah Gulen : $A$ vision of trancedent education, Fethullah Gulen Oficial web : e-paper, 2011

Parekh, Bikku. Dalam Dewi“ Lucia Ratih Kusuma. "Kembalinya Subyek: sosiologi memaknai kembali multkulturalisme" Jurnal sosiologi masyarakat.

Enginer, Asghar Ali. Islam dan Teologi Pembebasan, Yogyakarta : Pustaka Pelajar, 1999.

Fazlurrahman, Islam terj. Ahsin Muhammad, Bandung : Pustaka Salman, 1990.

Giddens, Athony. The Consequences of Modernity, Cambrigdge : Polity Press, 1990.

Gulen, Fethullah. " Toward Global Civilization of Love and Tolerance " New jersey, The Light, 2004.

Gulen, Fethullah. Essay, Persfektives, and Opinion, New jersey, Thugra Books, 2009.

http://nasional.kompas.com/read/2012/1 2//Lima.Kasus.Diskriminasi.Terburuk.Pasc areformasi.

Iqbal, Muhammad. The Reconstruction of Religious Thought in Islam, Lahore, 1975.

Jarir, Ibnu. Tari $>$ kh al-Thabari, Kairo : Da $>\mathrm{r}$ al-ma'arif 1963.

Kimball, Charles. When Religion Become Evil terj. Nurhadi dan Izzudin wasil, Bandung : Mizan, 2013.
Kuntowijoyo. Islam Sebagai Ilmu, Yogyakarta : Tiara Wacana, 2006.

Kuntowijoyo. Paradigma Islam, Bandung : Mizan, 2008.

Madjid, Nurcholis. Islam Kemodernan dan Keindonesiaan, Bandung: Mizan, 1999.

Nasution, Harun. Teologi Islam: aliranaliran, sejarah, analisa dan perbandingan, jakarta : UI Press, 2012.

Ridwan, AH. Reformasi Intelektual Islam, Yogyakarta : Ittaqa press, 1998.

Ritzer, George. Teori Sosiologi ; Dari Sosilogi klasik Sampai Perkembangan Terakhir Posmodern, Yogyakarta, Pustaka pelajar, 2012.

Rusyd, Ibnu Fasl al-Maqa>l fi ma> bain alHikmah wa Asy Syaari'ah min alIttisa>l. Mesir: Dar al-Ma'arif, t.t.

Saeed, Abdullah. Islamic Thought: an Introduction, New York : Rouledge, 2006.

Safi, Omid. Progressive Muslims; on Justice, Gender and Pluralisme, British, Oneworld Oxford, 2008.

Shoelhi, Mohammad (ed). Demokrasi Madinah: Model Demokrasi cara Rasulullah, Jakarta : Republika,2003.

Sugiharto, Bambang. Postmodernisme tantangan bagi filsafat, Yogyakarta : Kanisius, 1996.

Watt, Wiliam Montngomery. Muhammad Prophet and Statesman, Oxford University Press, 1961.

Weller, Paul and Yilmaz, (ed). European Muslim, Civility and Public life, India : 
POTRET PEMIKIRAN - Vol.20, No. 1, Januari - Juni 2016

Continuum International publishing Group. 2012. 